\title{
El coronavirus, el testamento en situación de epidemia y el uso de las TICs en el derecho español*
}

\section{Francisca Ramón Fernández}

RESUMEN. La declaración del estado de alarma en España por la epidemia de coronavirus ha activado la posibilidad de otorgar testamento para caso de epidemia regulado en el código civil español. Nos proponemos analizar este tipo de testamento, así como la aplicación de las nuevas tecnologías de la información y la comunicación teniendo en cuenta la situación del sujeto y las circunstancias en las que se puede encontrar, además de los problemas jurídicos que se pueden plantear.

Palabras clave: pandemia, coronavirus, testamento, epidemia, código civil español, TICS.

* Fecha de recepción: 8 de abril de 2020. Fecha de aceptación: 28 de agosto de 2020

Para citar el artículo: RAMÓn FERNÁNDEZ, F., "El coronavirus, el testamento en situación de epidemia y el uso de las tics en el derecho español", Revista de Derecho Privado, Universidad Externado de Colombia, n. ${ }^{\circ} 40$, enero-junio 2021, 395-435, Dor: https://doi.org/10.18601/01234366.n40.14.

Artículo de investigación realizado en el marco del Proyecto I+D+i "Retos investigación" del Programa estatal de I+D+i orientado a los Retos de la Sociedad del Ministerio de Ciencia, Innovación y Universidades: RTI2018-097354-B-100. "Contratos, transparencia y protección de datos en el mercado digital” (2019-2022). Investigadores Principales: Javier Plaza Penadés, catedrático de Derecho Civil, y Luz M. Martínez Velencoso, catedrática de Derecho Civil. Universitat de València-Estudi General.

** Escuela Técnica Superior de Ingeniería del Diseño (ETSID), Departamento de Urbanismo, Universitat Politècnica de València, Valencia, España; profesora titular de Derecho Civil. Doctora en Derecho, Universitat de València, Valencia, España. Licenciada en Derecho, Universitat de València, Valencia, España. Contacto: frarafer@urb.upv.es. Orcid: 0000-0002-0936-8229. 


\section{The Will for an Epidemic in the Spanish Civil Code and Use of ICTS}

Abstract. The declaration of the state of alarm in Spain for the coronavirus epidemic has activated the possibility of making a will in the event of an epidemic regulated in the Spanish Civil Code. We propose to analyze this type of will, as well as the application of new information and communication technologies taking into account the situation of the subject and the circumstances in which it may be found, and the legal problems that may arise.

KEYwORDS: saviour pandemic, coronavirus, will, epidemic, Spanish Civil Code, ICTS.

SumARIO. Introducción. I. El estado de alarma en España por la pandemia del coronavirus. II. El otorgamiento de testamento en estado de alarma en España: algunas cuestiones. III. Legislación aplicable al testamento en caso de epidemia. IV. El testamento en caso de epidemia: un testamento efímero. v. Las nuevas tecnologías de la información y la comunicación (TICS) y su aplicación al testamento en caso de epidemia. vi. Propuesta de regulación del testamento en caso de epidemia por parte de la Asociación de Profesores de Derecho Civil de España. viI. Otros tipos de testamento que se pueden otorgar. Conclusiones. Referencias.

\section{Introducción}

La situación de alerta sanitaria en la que nos encontramos en este momento en España, habiéndose declarado el estado de alarma por el Real Decreto 463/2020, de 14 de marzo, para la gestión de la situación de crisis sanitaria ocasionada por el Covid$19^{[1]}$, prorrogado posteriormente por el Real Decreto 476/2020, de 27 de marzo $^{2}$, ha conllevado la adopción de una serie de medidas, entre ellas, la restricción de la libre

1 воE, 67, de 14/03/2020, [en línea], disponible en: https://www.boe.es/buscar/doc.php?id=BOEA-2020-3692 [consultado el 6 de junio de 2020]. Modificado por Real Decreto 465/2020, de 17 de marzo, por el que se modifica el Real Decreto 463/2020, de 14 de marzo, por el que se declara el estado de alarma para la gestión de la situación de crisis sanitaria ocasionada por el Covid-19 (BOE, 73, de 18/03/2020, [en línea], disponible en: https://www.boe.es/buscar/doc.php?id=BOE-A-2020-3828 [consultado el 6 de junio de 2020]). Previamente a la declaración del estado de alarma, ya se había publicado el Real Decreto-Ley 6/2020, de 10 de marzo, por el que se adoptan determinadas medidas urgentes en el ámbito económico y para la protección de la salud pública (воE, 62, de 11/03/2020, [en línea], disponible en: https://www.boe.es/buscar/doc.php?id=BOE-A-2020-3434 [consultado el 6 de junio de 2020]), indicando que se "adopta un conjunto de medidas de carácter urgente dirigidas a dos ámbitos específicos, el económico y la salud pública, que en estos momentos demandan una respuesta inmediata".

2 BOE, 86, de 28/03/2020, [en línea], disponible en: https://www.boe.es/buscar/doc.php?id=BOEA-2020-4155 [consultado el 6 de junio de 2020]. Véase también la Resolución de 25 de marzo de 2020, del Congreso de los Diputados, por la que se ordena la publicación del Acuerdo de autorización de la prórroga del estado de alarma declarado por el Real Decreto 463/2020, de 14 de marzo (воE, 88, de 30/03/2020, [en línea], disponible en: https://www.boe.es/buscar/doc.php?id=BOEA-2020-4170 [consultado el 6 de junio de 2020]). 
circulación contemplada en el artículo 17 de la Constitución española. Una situación de pandemia que no solo ha afectado a España, sino que está extendida por toda Europa y el resto de continentes ${ }^{3}$.

Este estado de alarma se fundamenta, como indica el Real Decreto 463/2020, en "la acción decidida del Gobierno para proteger la salud y seguridad de los ciudadanos, contener la progresión de la enfermedad y reforzar el sistema de salud pública. Las medidas temporales de carácter extraordinario que ya se han adoptado por todos los niveles de gobierno deben ahora intensificarse sin demora para prevenir y contener el virus y mitigar el impacto sanitario, social y económico"4.

Todo ello ha supuesto un escenario insólito en el que se han producido numerosos cambios en la vida cotidiana. Precisamente por esta situación, se ha producido la posibilidad de aplicar un precepto del código civil que estaba en desuso ya que la situación que contemplaba era inimaginable en la época actual.

Nos estamos refiriendo al artículo 701 c.c. español que data de 1889 , y que hasta ahora no se había aplicado. Es cierto que los tiempos de pandemia habían quedado atrás; enfermedades como la peste, el cólera o la llamada "gripe española", que se dieron a lo largo del siglo XIX ${ }^{5}$, no se habían reproducido en los últimos tiempos. Era en esas situaciones que tenía lugar el testamento en caso de epidemia, en una redacción muy similar a la que actualmente conocemos en el texto legal actual.

Sin embargo, el escenario actual dista mucho del de hace dos siglos, y es por ello que las nuevas tecnologías de la información y la comunicación (TICS) tienen mucho

3 Ramos, C. "Covid-19: la nueva enfermedad causada por un coronavirus", [en línea], Salud Pública de México, vol. 62, n. ${ }^{\circ}$ 2, 2020, 225-227, disponible en: http://saludpublica.mx/index.php/spm/article/view/11276/11857 [consultado el 3 de abril de 2020].

4 Véase, al respecto, Álvarez, V. J., "El coronavirus (Covid-19): respuestas jurídicas frente a una situación de emergencia sanitaria”, [en línea], El Cronista del Estado Social y Democrático de Derecho, n. ${ }^{\circ}$ 86-87, 2020, 6-21, disponible en: http://www.elcronista.es/El-Cronista-n\%C3\%BAmero86-87-Coronavirus.pdf [consultado el 30 de marzo de 2020]; Cotino, L., "Confinamientos, libertad de circulación y personal, prohibición de reuniones y actividades y otras restricciones de derechos por la pandemia del Coronavirus", [en línea], en La Ley, n. ${ }^{\circ}$ 9606, 2020, 1-20, disponible en: https://diariolaley.laleynext.es/Content/Documento.aspx?params=H4siAAAAAAAEAMtMSbF1cTEAAmMDcwtjM7Wy1KLizPw8Wymdi6CYsYFaXn5KaoiLs21pXkpqWmZeagpiswzapUt-ckhlQaptWmJOcapaalJ-fjaKSfEwEwBQIndEYwAAAA==wKE [consultado el 6 de abril de 2020]; "Los derechos fundamentales en tiempos del coronavirus: régimen general y garantías y especial atención a las restricciones de excepcionalidad ordinaria", [en línea], El Cronista del Estado Social y Democrático de Derecho, n. ${ }^{\circ}$ 86-87, 2020, 88-101, disponible en: http://www.elcronista.es/ElCronista-n\%C3\%BAmero-86-87-Coronavirus.pdf [consultado el 3 de abril de 2020]; NogueIRA, A., "Confinar el coronavirus: entre el viejo derecho sectorial y el derecho de excepción", [en línea], $E l$ Cronista del Estado Social y Democrático de Derecho, n. ${ }^{\circ} 86-87,2020,22-31$, disponible en: http:// www.elcronista.es/El-Cronista-n\%C3\%BAmero-86-87-Coronavirus.pdf [consultado el 30 de marzo de 2020]; VelASCO, F., "Estado de alarma y distribución territorial del poder", [en línea], El Cronista del Estado Social y Democrático de Derecho, n. ${ }^{\circ}$ 86-87, 2020, 78-87, disponible en: http://www.elcronista.es/El-Cronista-n\%C3\%BAmero-86-87-Coronavirus.pdf [consultado el 5 de abril de 2020].

5 De Lara, M. J., "Epidemia, testamento e historia de las mentalidades: morir de peste en la Huelva del siglo XVII", en SERRANo, E. (coord.), Muerte, religiosidad y cultura popular: siglos XIII-XVIII, Zaragoza, Instituto "Fernando el Católico", 393-432. 
que decir en un ámbito, como es el sucesorio, que no ha sido adaptado a los tiempos actuales, y precisamente en lo que concierne a un acto tan decisivo en el ámbito personal como es el testamento.

Nos proponemos en el presente trabajo, como objetivo principal, realizar un análisis de este tipo de testamento en la situación en la que nos encontramos de pandemia, así como de los problemas jurídicos que se pueden plantear y de la aplicación de las nuevas tecnologías de la información y la comunicación como elemento a tener en cuenta a la hora del otorgamiento del testamento y sus posteriores efectos. Junto a ello, como objetivos secundarios, se hará referencia a los otros tipos de testamento que se pueden otorgar, para el supuesto de que no se pueda otorgar el testamento en caso de epidemia, por no disponer de los requisitos para su otorgamiento, especialmente los testigos.

La metodología utilizada en el presente estudio se centra en el análisis de la legislación aplicable, en el ámbito del derecho civil español, en relación con el testamento en caso de epidemia, así como en el examen de las principales y más recientes aportaciones doctrinales en la materia, para sobre esa base presentar una nueva perspectiva para su aplicación jurídica y contribuir a la investigación en el ámbito sucesorio en el derecho español. Del mismo modo, esta metodología hará posible abordar los principales problemas que se plantean en relación con el testamento en caso de epidemia, así como las distintas cuestiones en relación con las nuevas tecnologías de la información y la comunicación.

\section{El estado de alarma en España por la pandemia del coronavirus}

En el momento actual, España está inmersa en una situación de estado de alarma, y han sido numerosas las normas que el ejecutivo ha elaborado y que se han aprobado desde el inicio de la situación crítica originada en la pandemia del coronavirus. No es nuestra intención realizar una enumeración exhaustiva de ellas, sino centrarnos en las que pueden ser relevantes para la materia objeto de nuestro estudio: el testamento.

El estado de alarma se contempla en el artículo 116 de la Constitución española, el cual indica que será una ley orgánica la que regulará los tres estados de carácter excepcional que se pueden producir: estado de alarma, de excepción y de sitio.

El estado de alarma es declarado por el Gobierno mediante un decreto acordado en Consejo de Ministros por un plazo máximo de quince días, y de él se debe dar cuenta al Congreso de los Diputados, que se reunirá inmediatamente, debiendo este dar su autorización para que dicho estado de alarma pueda ser prorrogado, como ha ocurrido en el caso actual.

Para el caso presente, el decreto determinó que el ámbito territorial fuera todo el Estado español. 
La Ley Orgánica a que se refiere la Constitución española es la actual Ley Orgánica $4 / 1981$, de $1 .^{\circ}$ de junio, de los estados de alarma, excepción y sitio ${ }^{6}$.

En la situación de estado de alarma, como indica el artículo 55 de la Constitución, no se suspenden los derechos reconocidos en los artículos 17, 18 (apartados 2 y 3), 19, 20 (apartados 1, a. y d., y 5), 21, 28 (apartado 2) y 37 (apartado 2), contrariamente a lo que sucede en los estados de excepción o de sitio.

Sin embargo, sí hay restricciones en el estado de alarma, como es el caso de la libertad de las personas, pues una de las medidas adoptadas ha sido la del confinamiento de la población para evitar el contagio incontrolado del virus.

Además, se han promulgado distintas normas respecto al ámbito económico y social para paliar la situación, siendo de especial interés destacar el Real DecretoLey $11 / 2020$, de 31 de marzo, por el que se adoptan medidas urgentes complementarias en el ámbito social y económico para hacer frente al Covid-19 ${ }^{[7]}$, y el 10/2020, de 29 de marzo, por el que se regula un permiso retribuido recuperable para las personas trabajadoras por cuenta ajena que no presten servicios esenciales, con el fin de reducir la movilidad de la población en el contexto de la lucha contra el Covid-19 ${ }^{[8]}$.

Por su parte, el Real Decreto 463/2020, en su artículo 7, referente a la limitación de la libertad de circulación de las personas ${ }^{9}$, indica:

1. Durante la vigencia del estado de alarma las personas únicamente podrán circular por las vías de uso público para la realización de las siguientes actividades:

a) Adquisición de alimentos, productos farmacéuticos y de primera necesidad.

b) Asistencia a centros, servicios y establecimientos sanitarios.

c) Desplazamiento al lugar de trabajo para efectuar su prestación laboral, profesional o empresarial.

d) Retorno al lugar de residencia habitual.

e) Asistencia y cuidado a mayores, menores, dependientes, personas con discapacidad o personas especialmente vulnerables.

f) Desplazamiento a entidades financieras y de seguros.

g) Por causa de fuerza mayor o situación de necesidad.

6 BOE, 134, de 05/06/1981, [en línea], disponible en: https://www.boe.es/buscar/doc.php?id=BOEA-1981-12774 [consultado el 5 de junio de 2020].

7 BOE, 91, de 01/04/2020, [en línea], disponible en: https://www.boe.es/buscar/doc.php?id=BOEA-2020-4208 [consultado el 6 de junio de 2020].

8 BOE, 87, de 29/03/2020, [en línea], disponible en: https://www.boe.es/buscar/doc.php?id=BOEA-2020-4166 [consultado el 6 de junio de 2020].

9 Nieto, A. J., "El control social y la libre circulación de personas en tiempos del coronavirus", [en línea], La Ley, n. ${ }^{\circ}$ 9609, 7 de abril de 2020, 2, disponible en: https://diariolaley.laleynext.es/Content/ Documento.aspx ?params=H4siAAAAAAAEAMtMSbF1CTEAAmMDc3MzE7Wy1KLizPw8Wymdi6CY kRlimdot0iU_OaSyinu2Ltgnobuah6d_yzuaAaA=wKe [consultado el 7 de abril de 2020], indica: "En torno al concepto de generalidad y prohibición de libertad de deambulación. No existe una norma general estricta en la que se defina la prohibición de deambulación de los ciudadanos, sino que el Real Decreto, al amparo del conocimiento general de la ciudadanía del fin de la norma y su instrumento divulgativo 'Quédate en casa', tan sólo señala las excepciones de la norma que da por hecho haberlo establecido". 
h) Cualquier otra actividad de análoga naturaleza que habrá de hacerse individualmente, salvo que se acompañe a personas con discapacidad o por otra causa justificada.

2. Igualmente, se permitirá la circulación de vehículos particulares por las vías de uso público para la realización de las actividades referidas en el apartado anterior o para el repostaje en gasolineras o estaciones de servicio.

3. En todo caso, en cualquier desplazamiento deberán respetarse las recomendaciones y obligaciones dictadas por las autoridades sanitarias.

4. El Ministro del Interior podrá acordar el cierre a la circulación de carreteras o tramos de ellas por razones de salud pública, seguridad o fluidez del tráfico o la restricción en ellas del acceso de determinados vehículos por los mismos motivos.

Cuando las medidas a las que se refieren los párrafos anteriores se adopten de oficio se informará previamente a las administraciones autonómicas que ejercen competencias de ejecución de la legislación del Estado en materia de tráfico, circulación de vehículos y seguridad vial.

Las autoridades estatales, autonómicas y locales competentes en materia de tráfico, circulación de vehículos y seguridad vial garantizarán la divulgación entre la población de las medidas que puedan afectar al tráfico rodado.

\section{El otorgamiento de testamento en estado de alarma en España: algunas cuestiones}

Al referirnos al estado de alarma hemos indicado una serie de medidas, entre ellas el confinamiento de la población. Este aislamiento o cuarentena preventiva, y también para los casos diagnosticados con el coronavirus, ha planteado si se puede otorgar testamento y cómo es posible otorgarlo.

El Real Decreto-Ley 10/2020, anteriormente mencionado, en su anexo indica que no se aplicará el permiso retribuido de que trata a las siguientes personas trabajadoras por cuenta ajena: "Las que prestan servicios en las notarías y registros para el cumplimiento de los servicios esenciales fijados por la Dirección General de Seguridad Jurídica y Fe Pública".

La Circular de la Comisión Permanente del Consejo General del Notariado de 18 de marzo de $2020^{[10]}$ establece una serie de reglas generales, estableciendo la excepcionalidad de la intervención notarial en la situación actual. La urgencia de la actuación debe ser interpretada de forma restrictiva, ya que el desplazamiento del notario para acudir a dar fe está, como el desplazamiento de cualquier sujeto, prohibido por el estado de alarma.

10 Comisión Permanente del Consejo General del Notariado, Circular de 18 de marzo de 2020, [en línea], disponible en: https://madrid.notariado.org/portal/documents/20828/22843/Circular_com_ permanente+18_03_20/4021a11f-47c6-44ac-b010-caebf1314449 [consultado el 6 de abril de 2020]. 
La urgencia no es equivalente ni se debe identificar con la fuerza mayor o fuerza irresistible, y deberá ser el notario el que aprecie las circunstancias que concurran, para formarse un juicio personal para citar o no al sujeto en su notaría. Las pautas a seguir para dicha ponderación serán las siguientes:

a) Naturaleza de la operación;

b) Existencia de plazos perentorios;

c) Existencia de graves perjuicios en caso de denegación, que revelen la apremiante necesidad del interesado.

El procedimiento a seguir será el que sigue. Para comenzar, la rogación por parte del interesado hacia el notario solicitando su intervención. La comunicación previa se podrá realizar a través del teléfono o del correo electrónico, indicando la razón de la urgencia para la intervención notarial. Se considera como forma preferente el correo electrónico, que además deja constancia del texto de la solicitud, siendo excepcional la comunicación telefónica, que queda relegada a las personas que no dispongan de medios telemáticos.

Si el notario considera que hay justificación en la urgencia de la solicitud de su intervención, citará al solicitante, en un día y a una hora concretos, también a través del correo electrónico o, de forma excepcional, mediante llamada telefónica, con la advertencia de que se deberá acudir a la oficina con los medios de autoprotección para garantizar la seguridad sanitaria (mascarilla, guantes, solución hidroalcohólica), además de mantener la distancia de seguridad recomendada una vez se haya acudido a la cita.

Se dejará constancia por escrito de la causa de la urgencia, en un archivo separado, reseñando el número de protocolo o asiento del libro registro, lo que permitirá justificar el cumplimiento de las medidas del ejecutivo tras declarar el estado de alarma.

Se establece la obligación de conservación documental de dicho archivo durante un plazo de cuatro años, a efectos de inspecciones de las juntas directivas de los colegios notariales, la administración o la judicatura.

Están exceptuados de la justificación de la urgencia determinadas actuaciones, entre las que no se encuentra el testamento. Además, en el caso de actos de naturaleza personal, la Circular matiza que "el notario habrá de valorar la urgencia en función de las circunstancias, sin que deba prestar su intervención si caben otros procedimientos alternativos que eviten el riesgo inherente al desplazamiento o que permitan el aplazamiento de su intervención". Al igual que en el caso de actuaciones fuera de la oficina notarial, siguiendo lo indicado en la Instrucción de la Dirección General de Seguridad Jurídica y Fe Pública de 15 de marzo de 2020 sobre la adopción de medidas que garanticen la adecuada prestación del servicio público notarial $^{11}$, no podrá prestar servicio. No obstante se admite "con carácter absolutamente

11 Dirección General de Seguridad Jurídica y Fe Pública, Instrucción de 15 de marzo de 2020 sobre la adopción de medidas que garanticen la adecuada prestación del servicio público notarial, [en 
excepcional" que pueda realizar salidas fuera de su despacho por estricta causa de fuerza mayor, de acuerdo con lo indicado en el artículo 7 del Real Decreto 463/2020.

En dicha situación de confinamiento, se plantea si el sujeto puede, de alguna forma, hacer testamento, teniendo en cuenta la situación de aislamiento. La respuesta es que sí, y el ordenamiento jurídico español facilita diferentes tipos de testamento, y en especial el que vamos a estudiar, el testamento en caso de epidemia, que tristemente es de actualidad, y que teniendo en cuenta lo indicado en la Circular referida no precisa de la intervención del notario.

Lo anterior no quiere decir que no se pueda hacer el testamento ante notario, que sí que podrá hacerse, siempre y cuando este considere como se trata de una situación de carácter urgente, ya que la situación de estado de alarma limita los desplazamiento y habrá que atender a lo indicado tanto en la Circular como en la Instrucción referidas y dictadas al amparo del artículo 339 del Reglamento Notarial ${ }^{12}$ que dispone:

La Comisión Permanente estará integrada por el Presidente, el Vicepresidente y tres Decanos designados por el Pleno. Se reunirá cuantas veces fuere necesario, previa convocatoria por el Presidente, por propia iniciativa o a petición fundada de cualquiera de sus miembros. Quedará válidamente constituida para su actuación en cada caso con la asistencia de la mayoría absoluta de sus componentes. De sus acuerdos se dará cuenta inmediata a todos los Decanos.

Podrá ejercer aquellas competencias que le delegue el Pleno del Consejo, asumiendo las funciones de éste en casos de urgencia. Los acuerdos adoptados por la Comisión Permanente en virtud de delegación del Consejo deberán expresar tal carácter y se entenderán adoptados por el órgano delegante, pudiendo ser objeto de recurso en los términos previstos en el artículo 343 de este Reglamento. Del resto de sus acuerdos dará cuenta a todos los Decanos.

No es delegable la condición de miembro de la Comisión Permanente, que se ostentará con carácter personal por todo el tiempo que el designado desempeñe el cargo de Decano.

línea], disponible en: https://ficheros.mjusticia.gob.es/pdf/Instrucci\%c3\%93N\%20DGsJyFP\%201503-2020.pdf [consultado el 6 de abril de 2020].

12 Precepto redactado por el número 210 del artículo primero del Real Decreto 45/2007, de 19 de enero, por el que se modifica el Reglamento de la organización y régimen del Notariado (BOE, 25, de 29/01/2007, [en línea], disponible en: https://www.boe.es/buscar/doc.php?id=BOE-A-2007-1810 [consultado el 7 de junio de 2020]), aprobado por Decreto de 2 de junio de 1944 (вOE, 189, de 07/07/1944, [en línea], disponible en: https://www.boe.es/buscar/doc.php?id=BOE-A-1944-6578 [consultado el 7 de junio de 2020]). 


\section{Legislación aplicable al testamento en caso de epidemia}

El presente acápite se ocupa de la legislación aplicable al testamento en caso de epidemia, teniendo en cuenta la distinción entre la legislación del código civil y la que se regula por distintas normas en los territorios de derecho foral, en diversas comunidades autónomas.

\section{A. Legislación estatal}

La situación de pandemia por coronavirus en España ha traído a la actualidad la figura del testamento en caso de epidemia, figura jurídica que se dudaba que algún día pudiera llegar a aplicarse. Sin embargo, por las razones anteriormente expuestas, la situación de epidemia hace que pueda ser necesario acudir a este tipo testamentario.

No se trata de un testamento especial, ya que los testamentos especiales son el militar, el marítimo y el hecho en país extranjero. Se trata de un testamento abierto, oral o nuncupativo ${ }^{13}$, pero sin necesidad de presencia del notario, y que sí que precisa la presencia de tres testigos. Algún sector de la doctrina lo califica como de pretestamento, ya que los testamentos que se otorgan sin autorización de notario son ineficaces si no se elevan a escritura pública y se protocolizan (art. 704 c.c.). Además es un testamento dijéramos efímero, ya que se considera ineficaz si pasan dos meses desde que cesa la epidemia (art. 703 c.c.) $)^{14}$.

Como hemos visto en el punto anterior, la presencia de un notario en una situación de confinamiento de pandemia no es cuestión baladí, ya que va a depender del criterio del notario el que se pueda otorgar o no testamento, no aquel del supuesto de la epidemia, sino un testamento abierto normal. Si no se puede, entonces entra en juego el supuesto del testamento en caso de epidemia, que prescinde del notario para poderse realizar, pero que posteriormente deberá protocolizarse ante notario, que además tiene que reunir una serie de requisitos, y cuya validez queda limitada temporalmente.

En el derecho civil español se regula actualmente el testamento en caso de epidemia en el artículo 701 c.c., integrado dentro del Libro Tercero, "De los diferentes modos de adquirir la propiedad", del Título III, "De las sucesiones", en la Sección Quinta, "Del testamento abierto".

Como todo testamento, es un acto de disposición para después de la muerte de todos los bienes o parte de estos que puede realizar una persona siempre que tenga capacidad para ello, es decir, que sea mayor de catorce años y que no se encuentre

13 Ripoll, A., "Testamentos en caso de epidemia y en peligro de muerte", [en línea], Notarios y Registradores, 2020, 1, disponible en: https://www.notariosyregistradores.com/web/secciones/oficinanotarial/otros-temas/testamento-en-caso-de-epidemia-y-en-peligro-de-muerte/ [consultado el 7 de abril de 2020].

14 Irurzun, D., "Testamentos y pretestamentos: (... 'sin necesidad de Notario'. Artículo 700 CC)", Revista Jurídica del Notariado, n. ${ }^{\circ}$ 69, 2009, 71. 
en la situación que indica el artículo 663 c.c. como incapacitado para testar: "el que habitual o accidentalmente no se hallare en su cabal juicio".

Se trata de una modalidad de testamento común, que integra el ológrafo, abierto o cerrado. No siendo un testamento especial, ya que son de este tipo, como se recordó previamente, el militar (art. 761 a 721 c.c.), el marítimo (arts. 722 a 731 c.c.) y el hecho en país extranjero (arts. 732 a 736 c.c.).

Se trata, pues, de un testamento que se puede otorgar en una situación excepcional, como es el caso de epidemia ${ }^{15}$, y que, al igual que el testamento en peligro inminente de muerte (art. 700 c.c.), se otorga sin presencia de notario.

\section{B. Legislación foral y autonómica}

Cabe destacar que en el ámbito foral, el testamento en caso de epidemia ha sido objeto de regulación específica. En algunos casos se remite a la regulación del código civil; en otros casos, no se permite, como es el caso de Cataluña, al no ser válido el testamento que se otorga solamente ante testigos. Veamos con detalle.

La Ley 10/2008, de 10 de julio, del libro cuarto del código civil de Cataluña ${ }^{16}$, relativo a las sucesiones, en su artículo 421-5.3, aplicable a quienes tengan vecindad civil catalana ${ }^{17}$, indica expresamente: "No son válidos los testamentos otorgados exclusivamente ante testigos".

La Ley 1/1973, de 1 de marzo, por la que se aprueba la Compilación del Derecho civil foral de Navarra ${ }^{18}$, modificada por la Ley Foral 21/2019, de 4 de abril, de modificación y actualización de la Compilación del Derecho civil foral de Navarra o Fuero Nuevo ${ }^{19}$, remite a la regulación del código civil respecto al testamento en caso de epidemia, ya que la Ley 193, que regula "Otros testamentos", indica: "Sin perjuicio de las especialidades contenidas en la presente Compilación, se aplicarán en Navarra las disposiciones del Código Civil relativas a los siguientes testamentos: el testamento otorgado en tiempo de epidemia, los testamentos militares y marítimos y el testamento hecho en país extranjero". Al igual que el artículo 22 de la Ley 5/2015,

15 Sobre el concepto, véase RIVERA, V., “"En caso de epidemia’: sentido y alcance de la peculiar locución del artículo 701 CC”, Revista de Derecho Privado, vol. 91, n. . 5, 2007, 81-92; RIVAs, J. J., "Artículo 701. Caso de epidemia", en Valpuesta, R. (coord.), Cañizares, A., De Pablo, P. y OrduÑA, F. J. (dir.), Código civil comentado. Libro III: De los diferentes modos de adquirir la propiedad (artículos 609 a 1087), Cizur Menor, Thomson Reuters-Civitas, 2011, 468-472.

16 BOE, 190, de 07/08/2008, [en línea], disponible en: https://www.boe.es/buscar/doc.php?id=BOEA-2008-13533 [consultado el 7 de junio de 2020].

17 López-Galiacho, J., "La 'rabiosa' actualidad del testamento en caso de epidemia", [en línea], Hay Derecho, 2020, 1, disponible en: https://hayderecho.expansion.com/2020/03/20/la-rabiosa-actualidad-del-testamento-en-caso-de-epidemia/ [consultado el 8 de abril de 2020].

18 ВоE, 57, de 7/03/1973, [en línea], disponible en: https://www.boe.es/buscar/doc.php?id=BOEA-1973-330 [consultado el 7 de junio de 2020].

19 воE, 137, de 8/06/2019, [en línea], disponible en: https://www.boe.es/buscar/doc.php?id=BOEA-2019-8512 [consultado el 7 de junio de 2020]. 
de 25 de junio, de Derecho Civil Vasco ${ }^{20}$, que establece que rigen todas las formas de testar reguladas en el código civil.

No lo contempla, pero no lo prohíbe, la Ley 2/2006, de 14 de junio, de Derecho civil de Galicia ${ }^{21}$, por lo que estimamos que debe aplicarse supletoriamente el código civil. Consideramos lo mismo en relación con el Decreto Legislativo 79/1990, de 6 de septiembre, por el que se aprueba el Texto Refundido de la compilación de Derecho civil de las Islas Baleares, que en su artículo 52 se remite al código civil ${ }^{22}$; y con el Decreto Legislativo 1/2011, de 22 de marzo, del Gobierno de Aragón, por el que se aprueba, con el título de "Código de Derecho Foral de Aragón”, el Texto Refundido de las Leyes civiles aragonesas ${ }^{23}$. En el Anteproyecto de Ley de la Generalitat, Valenciana de Sucesiones, de 24 de julio de $2009^{24}$, se contemplaba el testamento nuncupativo o de paraula ${ }^{25}$, en el artículo 39, que era aquel en que, sin presencia de notario, el testador declaraba su última voluntad de viva voz ante tres testigos rogados. Este testamento debía luego adverarse y protocolizarse, como señalaba el artículo 40 del Anteproyecto:

En el plazo de treinta días desde el otorgamiento del testamento nuncupativo, los tres testigos han de comparecer ante el Juez de Primera Instancia competente, ante el que declararán que ellos son los testigos del testamento nuncupativo del causante.

El Juez en presencia del Secretario del Juzgado y de los tres testigos recibirá la voluntad del causante por declaración separada de cada uno de ellos.

Las declaraciones de los testigos han de ser plenamente coincidentes en cuanto a la última voluntad del testador. Una vez depuestos los testimonios de los testigos que se recogerán por escrito, el Juez, a la vista de las declaraciones recibidas, dictará la resolución que proceda teniendo, en su caso, por última voluntad del causante la

20 BOE, 176, de 24/07/2015, [en línea], disponible en: https://www.boe.es/buscar/doc.php?id=BOEA-2015-8273 [consultado el 7 de junio de 2020].

21 BOE, 191, de 11/08/2006, [en línea], disponible en: https://www.boe.es/buscar/doc.php?id=BOEA-2006-14563 [consultado el 7 de junio de 2020].

22 BOIB, 120, de 2/10/1990, [en línea], disponible en: https://www.boe.es/buscar/doc.php?id=BOIBi-1990-90001 [consultado el 7 de junio de 2020].

23 BOA, 67, de 29/03/2011, [en línea], disponible en: https://www.boe.es/buscar/doc.php?id=BOAd-2011-90007 [consultado el 7 de junio de 2020].

24 Anteproyecto de Ley, de la Generalitat, valenciana de sucesiones de 24 de julio de 2009, [en línea], disponible en: https://www.notariosyregistradores.com/PROYECTOS/proyectos\%20concretos/ Valencia-sucesiones.pdf [consultado el 7 de abril de 2020].

25 Significa "de palabra". Se trata de una expresión en lengua valenciana. Véase sobre ello GiMÉNEZ, V. y Ramón, F., "El testamento nuncupativo: del derecho foral a la futura regulación sucesoria valenciana", [en línea], Revista de Derecho Civil Valenciano, n. . 6, 2009, 1-9, disponible en: http:// derechocivilvalenciano.com/revista/numeros/6-segundo-semestre-2009/item/15-el-testamentonuncupativo-del-derecho-foral-a-la-futura-regulacion-sucesoria-valenciana [consultado el 7 de abril de 2020]. 
testimoniada por los tres testigos. En este caso, el juez ordenará en la resolución que ésta se protocolice notarialmente con el encargo al notario de que tras la muerte del testador proceda a su publicación.

Actualmente el Anteproyecto se encuentra paralizado tras las sentencias del Tribunal Constitucional 82/2016, de 28 de abril ${ }^{26}$; 110/2016, de 9 de junio ${ }^{27}$, y 192/2016, de 16 de noviembre ${ }^{28}$, en las que se consideró la falta de competencia legislativa autonómica valenciana.

\section{Legislación en el derecho comparado}

En el ámbito del derecho comparado, el testamento en caso de epidemia se ha contemplado en la legislación de Portugal e Italia ${ }^{29}$. Así, el artículo 609 c.c. italiano lo contempla en su artículo 609, cuando se refiere a las enfermedades contagiosas, calamidades públicas o infortunios ${ }^{30}$ :

\section{Articolo 609. Malattie contagiose, calamità pubbliche o infortuni}

Quando il testatore non può valersi delle forme ordinarie (601 e seguenti), perché si trova in luogo dove domina una malattia reputata contagiosa, o per causa di pubblica calamità o d'infortunio, il testamento è valido se ricevuto da notario, dal pretore o dal conciliatore del luogo, dal sindaco o da chi ne fa le veci, o da un ministro di culto, in presenza di due testimoni di età non inferiore a sedici anni. Il testamento è redatto e sottoscritto da chi lo riceve; ̀̀ sottoscritto anche dal testatore e dai testimoni. Se il testatore o i testimoni non possono sottoscrivere, se ne indica la causa.

Por su parte, el código civil portugués, en su artículo 2220, lo contempla para el caso de testamento hecho en caso de calamidad pública ${ }^{31}$ :

26 воE, 131, de 31/05/2016, [en línea], disponible en: http://hj.tribunalconstitucional.es/es-ES/Resolucion/Show/24936 [consultado el 7 de junio de 2020].

27 BOE, 70, de 9/06/2016, [en línea], disponible en: http://hj.tribunalconstitucional.es/es-ES/Resolucion/Show/25013 [consultado el 7 de junio de 2020].

28 BOE, 311, de 26/12/2016, [en línea], disponible en: http://hj.tribunalconstitucional.es/es-ES/Resolucion/Show/25162 [consultado el 7 de junio de 2020].

29 López-Galiacho, J., "La 'rabiosa' actualidad del testamento en caso de epidemia”, cit., 3.

30 Regio Decreto de 16 de marzo de 1942, n. ${ }^{\circ}$ 262, Approvazione del testo del Codice civile (042U0262) [en línea], GU, 79, de 04/04/1942, disponible en: https://www.normattiva.it/uri-res/ N2Ls?urn:nir:stato:codice.civile:1942-03-16;262 [consultado el 7 de junio de 2020].

31 Decreto-Ley 47344, de 25 de novembro de 1966, código civil portugués 19 [en línea], disponible en: https://www.igac.gov.pt/documents/20178/358682/C\%C3\%B3digo+Civil.pdf/2e6b36d8-876b433c-88c1-5b066aa93991 [consultado el 7 de junio de 2020]. 
Artigo 2220 (Testamento feito em caso de calamidade pública)

1. Se qualquer pessoa estiver inibida de socorrer-se das formas comuns de testamento, por se encontrar em lugar onde grasse epidemia ou por outro motivo de calamidade pública, pode testar.perante algum notário, juíz ou sacerdote, com observância das formalidades prescritas nos artigos $2211^{\circ}$ ou $2212^{\circ} .2 .2$. O testamento será depositado, logo que seja possível, na repartição notarial ou em alguma das repartições notariais do lugar onde foi feito.

\section{El testamento en caso de epidemia: un testamento efímero}

\section{A. Requisitos para otorgarlo}

El testamento en caso de epidemia se puede otorgar sin la intervención de notario y en presencia de tres testigos, que tienen que ser mayores de dieciséis años, tal y como preceptúa el artículo 701 c.c. español. Este precepto fue redactado por la Ley de 24 de abril de 1958 por la que se modificaron determinados artículos del código civil ${ }^{32}$. La redacción original del artículo indicaba: "En caso de epidemia puede igualmente otorgarse el testamento sin intervención de Notario ante tres testigos mayores de diez y seis años, varones ó mujeres" 33 .

En la redacción inicial del artículo 702 c.c. se precisaba que el testamento se escribiría si fuera posible, y si no lo fuera, valdría el testamento a pesar de que los testigos no sepan escribir ${ }^{34}$. La redacción se mantiene en la actualidad: se da la opción de escritura de la voluntad del testador, pero considerándose válido si no se escribe porque los testigos no sepan escribir, o incluso, consideramos, en caso de no escribirse por no disponer de ningún soporte para ello. Entonces, se estaría ante el supuesto de un testamento oral sin redacción por escrito de la última voluntad, que posteriormente deberá cumplir las indicaciones de los preceptos 703 y 704 c.c., como veremos a continuación.

Los testigos para el otorgamiento de testamento en caso de epidemia deben ser personas que no estén excluidas por el artículo 681 (salvo lo dispuesto para el testamento en caso de pandemia, en el que sí pueden serlo los menores de edad mayores de 16 años), esto es:

a) Los que no entiendan el idioma del testador. Aquí se incluiría el lenguaje de signos, en el caso de sordomudos;

32 BOE, 99, de 25/04/1958, [en línea], disponible en: https://www.boe.es/buscar/doc.php?id=BOEA-1958-6677 [consultado el 7 de junio de 2020].

33 Código civil [en línea], Gaceta de Madrid,318, de 11/11/1888, disponible en: https:/www.boe.es/ datos/pdfs/BOE//1888/316/A00445-00445.pdf [consultado el 7 de junio de 2020].

34 Ibíd. 
b) Los que no presenten el discernimiento necesario para desarrollar la labor testifical;

c) El cónyuge o los parientes dentro del cuarto grado de consanguinidad o segundo de afinidad del Notario autorizante y quienes tengan con éste relación de trabajo.

En este último caso, como el otorgamiento del testamento es sin presencia del notario, el precepto es de dudosa aplicación al testamento en caso de epidemia, ya que no hay notario autorizante.

Este precepto quedó así redactado por la Ley 15/2015, de 2 de julio, de Jurisdicción Voluntaria ${ }^{35}$, que eliminó el supuesto de que no podían ser testigos en los testamentos los ciegos y los totalmente sordos o mudos, que actualmente sí pueden serlo.

También se redactó en términos más acordes con la realidad social el supuesto del entendimiento, ya que en la redacción anterior a la Ley 15/2015 se prohibía a "los que no estén en su sano juicio".

Nótese que el artículo 701 c.c. hace referencia a testigos y de una edad concreta: mayores de dieciséis años, pero no menciona, tal y como hace el artículo 700 del mismo texto legal, que sean idóneos.

Tampoco podrán ser testigos, según establece el artículo 682 c.c., los herederos y legatarios en él instituidos, sus cónyuges, ni los parientes de aquellos, dentro del cuarto grado de consanguinidad o segundo de afinidad.

No se comprende dentro de esta prohibición a los legatarios ni sus cónyuges o parientes en el caso de que el legado sea de algún objeto mueble, para lo cual se tendrá en cuenta la diferencia establecida en los artículos 333 y siguientes c.c., o sea, que se trate de una cantidad de poca importancia con relación al caudal hereditario.

Los testigos, según indica el artículo 685 c.c., en el supuesto de testamento en caso de pandemia y en el de peligro inminente de muerte, tendrán la obligación de conocer al testador y procurarán asegurarse de su capacidad.

\section{B. Requisitos para su validez}

Junto a la oralidad, que también se da en el testamento abierto notarial, el otorgamiento es más sencillo, no precisándose la intervención de notario, si bien esto, como hemos indicado, de forma inicial, ya que posteriormente sí será necesaria su intervención ${ }^{36}$.

$35 B O E, 158$, de 3/07/2015, [en línea], disponible en: https://www.boe.es/buscar/doc.php?id=BOEA-2015-7391 [consultado el 7 de junio de 2020]. Dicha ley fue modificada por Ley 4/2017, de 28 de junio (BOE, 154, de 29/06/2017, [en línea], disponible en: https://www.boe.es/buscar/doc. php?id=BOE-A-2017-7483 [consultado el 7 de junio de 2020]).

36 Rivas, J. J., “Artículo 702. Forma testamentaria de los artículos 700 y 701”, en VAlpuesta FernáNdez, R. (coord.), Cañizares Laso, A., De Pablo, P. y Orduña, F. J. (dirs.), Código civil comentado. Libro III: De los diferentes modos de adquirir la propiedad (artículos 609 a 1087), cit., 472-474. 
La validez del testamento no queda afectada porque no se redacte por escrito, ya que el artículo 702 c.c. así lo indica. Es decir que, aunque los testigos no sepan escribir, el testamento será válido.

Sin embargo, esta modalidad de testamento abierto tiene una peculiaridad que lo hace distinto a los otros tipos de testamento, a excepción del testamento en peligro inminente de muerte, a saber, su tiempo de validez. Hemos dicho que es un testamento efímero, y pueden darse dos escenarios: que el testador viva cuando al terminar la epidemia, o bien que el testador muera durante el plazo que prescribe el artículo 703 c.c.

El testamento en caso de epidemia deviene ineficaz si pasaren dos meses desde que haya cesado la epidemia, caso en el cual se aplica lo indicado en el artículo 5 c.c. respecto al cómputo de los plazos:

1. Siempre que no se establezca otra cosa, en los plazos señalados por días, a contar de uno determinado, quedará éste excluido del cómputo, el cual deberá empezar en el día siguiente; y si los plazos estuviesen fijados por meses o años se computarán de fecha a fecha. Cuando en el mes del vencimiento no hubiera día equivalente al inicial del cómputo, se entenderá que el plazo expira el último del mes.

2. En el cómputo civil de los plazos no se excluyen los días inhábiles.

En el caso de fallecimiento del testador dentro de los dos meses, el testamento deviene ineficaz si dentro de los tres meses siguientes al fallecimiento no se acude al notario competente para que lo eleve a escritura pública, ya se haya otorgado por escrito, ya verbalmente. Hay que tener en cuenta que puede estarse todavía en situación de epidemia, ya que esta puede no haber cesado.

Como indica el artículo 704 c.c., los testamentos que se otorgan sin autorizarse notarialmente son ineficaces si no se elevan a escritura pública y se procede a su protocolización. Ello se aplica al testamento en caso de epidemia. Nos encontramos ante el procedimiento notarial de jurisdicción voluntaria ${ }^{37}$.

\section{Problemas que se pueden plantear}

Hemos visto que el testamento en caso de epidemia es un testamento para un caso excepcional, y por ello las condiciones en las que se puede otorgar difieren de las habituales para otorgar la última voluntad ${ }^{38}$, pero no por ello queda exento de cues-

37 Ripoll, A., "Procedimiento notarial de jurisdicción voluntaria: los testigos", Revista Jurídica del Notariado, n. ${ }^{\circ}$ 99, 2016, 551-584. Véase también Vela, A. J., "El testamento en tiempo de epidemia: cuestiones esenciales", [en línea], La Ley, n. ${ }^{\circ}$ 9623, 2020, 1-8, disponible en: https://diariolaley.laleynext.es/dll/2020/04/29/el-testamento-en-tiempo-de-epidemia-cuestiones-esenciales [consultado el 6 de junio de 2020].

38 Ripoll, A., “Testamentos en caso de epidemia y en peligro de muerte”, cit., 2. 
tiones y problemas jurídicos que se pueden plantear en la interpretación de los preceptos que lo regulan.

Si se observa detenidamente la redacción del precepto 701 c.c.: "En caso de epidemia puede igualmente otorgarse el testamento sin intervención de notario ante tres testigos mayores de dieciséis años", se advierte que se utiliza el adverbio de modo "igualmente", que la doctrina ya ha señalado que es inapropiado ${ }^{39}$. Precisamente el "igualmente" se indica en un precepto que va después de la regulación del testamento en inminente peligro de muerte, cuando se trata en realidad de situaciones y circunstancias totalmente diferentes.

A lo anterior se agrega que mientras el artículo 700 c.c. indica "sin necesidad de notario", el artículo 701 señala "sin intervención de notario". Necesidad e intervención son conceptos totalmente distintos, aunque el resultado sea que no se necesite notario para ser otorgados. La necesidad se refiere a una situación imperante (el inminente peligro de muerte) que hace que no se necesite, que puede ser tan cercano el momento, que el notario no llegue, o esté tan lejos que no se pueda disponer de él en esos momentos. La intervención se refiere a una situación en la que no va a poder intervenir el notario, bien porque en el caso de epidemia, el notario puede tener una limitación de la libertad como el resto de ciudadanos, o puede contemplarse que pueda acudir a su puesto de trabajo, pero debe calibrar si su intervención es posible, porque hay que valorar todos los casos en los que el notario pueda intervenir en el caso de epidemia y de ahí que se contempla que el sujeto puede otorgar testamento sin su intervención.

Parece de Perogrullo, pero es necesario indicar que el testamento en caso de epidemia solo se puede otorgar precisamente cuando exista dicha situación, pero ello no es baladí, pues es preciso que haya una declaración de pandemia en el territorio, que puede ser extensiva a todo el Estado español o bien a una parte de su territorio, con lo cual hay que atender a la regulación por el derecho común o el especial o foral de la aplicación. En el caso del derecho común, se aplicaría el código civil tal y como lo estamos indicando, y sería aplicable a los territorios que no dispongan de derecho foral que regule específicamente esta situación, ya que el código civil es supletorio.

En el caso que nos ocupa, precisamente la Organización Mundial de la Salud (OMS) elevó la situación de emergencia de salud pública ocasionada por el Covid-19 a pandemia internacional el 11 de marzo de $2020^{[40]}$, con la posterior declaración del estado de alarma en España.

40 Organización Mundial de la Salud, [en línea], 2020, disponible en: https://www.who.int/es [consultado el 15 de marzo de 2020]. Véase también Ripoll, A., "Testamentos en caso de epidemia y en peligro de muerte", cit., 4 . 
Este testamento está sujeto a caducidad ${ }^{41}$, circunstancia que no se produce en los testamentos con intervención de notario, ya que en el caso del testamento en caso de pandemia se debe acreditar luego su autenticidad; en efecto, como indica el artículo 704 c.c., este testamento debe ser elevado a escritura pública y protocolizarse ${ }^{42}$ conforme a lo indicado en la Ley Orgánica del Notariado de 28 de mayo de $1862^{[43]}$ y en el Decreto de 2 de junio de 1944, por el que se aprueba con carácter definitivo el Reglamento de la Organización y Régimen del Notariado, al que hemos hecho referencia anteriormente.

Otro problema que se puede plantear es la capacidad del testador y la de los testigos. Nos hemos referido en un punto anterior a ello, pero vamos a precisar algunos detalles.

El testador debe tener capacidad, y ella se predica del estado en que se halle al tiempo de otorgar el testamento (art. 666 c.c.). Esta capacidad es necesaria y no es posible excluirla por el hecho de que se esté en un caso de pandemia.

No tiene, pues, que estar incapacitado para otorgar el testamento, es decir, no debe encontrarse dentro de los dos supuestos del artículo 663 c.c. (menor de catorce años de uno y otro sexo, y el que habitual o accidentalmente no se hallare en su cabal juicio). Aquí podríamos hacer referencia a lo que se ha denominado el testamento del incapacitado en intervalo lúcido ${ }^{44}$, ya que el artículo 665 c.c. indica:

Siempre que el incapacitado por virtud de sentencia que no contenga pronunciamiento acerca de su capacidad para testar pretenda otorgar testamento, el notario designará dos facultativos que previamente le reconozcan y no lo autorizará sino cuando éstos respondan de su capacidad.

Respecto a los testigos, se aplicará lo indicado en el artículo 681 c.c., con la excepción de la edad, puesto que podrán serlo los menores de edad que sean mayores de dieciséis años; así como los artículos 682 c.c., respecto de los cónyuges, parientes y legatarios, y 683 c.c., que señala que para que un testigo sea declarado inhábil es necesario que la causa de su incapacidad exista al tiempo de otorgarse el testamento.

41 Calaza, C. A., "Los testamentos sin intervención notarial y su eficacia en la "nueva normalidad", [en línea], La Ley, n. ${ }^{\circ}$ 9638, 2020, 1 y 4, disponible en: https://diariolaley.laleynext.es/d11/2020/05/22/ los-testamentos-sin-intervencion-notarial-y-su-eficacia-en-la-nueva-normalidad [consultado el 6 de junio de 2020].

42 Véase Ávila, P., Derecho notarial, Barcelona, Bosch, 1990, 129.

43 Gaceta de Madrid, 149, de 29/05/1862, [en línea], disponible en: https://www.boe.es/datos/pdfs/ BOE//1862/149/A00001-00001.pdf [consultado el 7 de junio de 2020].

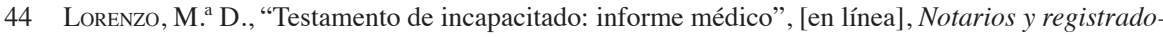
res, s. f., disponible en: https:/www.notariosyregistradores.com/AULASOCIAL/2012-testamento-discapacidad-informe-medico-665-codigo-civil.htm [consultado el 8 de abril de 2020]. Cfr. RoMERo, A . M. a "Testamento e intervalos lúcidos", Actualidad jurídica Aranzadi, n. ${ }^{\circ}$ 860, 2013, 5; BERROCAL, A. I., "La capacidad y voluntad de testar dos pilares fundamentales en la sucesión testada", Revista Crítica de Derecho Inmobiliario, n. ${ }^{\circ}$ 770, 2018, 3339-3371. 
No indica el artículo 701 c.c. que los testigos sean idóneos, a diferencia del artículo 700 c.c. que sí lo exige para el caso del testamento en peligro inminente de muerte, pero no consideramos que se pueda otorgar el testamento en caso de epidemia ante testigos no idóneos, o ante testigos que no lo pueden ser conforme al artículo 681 y 682 c.c., aunque no lo indique así el precepto.

Los testigos, además, como manda el artículo 685 in fine c.c., tendrán la obligación de conocer al testador y procurarán asegurarse de su capacidad.

El precepto diferencia entre el conocimiento del notario de la identidad del testador, que es obligatorio, y el deber del notario de asegurarse de que tiene capacidad para testar, es decir, que hará "diligencias o esfuerzos para que suceda lo que se expresa”, pues este el significado del verbo transitivo según la RAE ${ }^{45}$.

La doctrina también ha sugerido las razones por las cuales el número de testigos es de tres, y no de cinco como se precisa para el testamento en inminente peligro de muerte. En caso de pandemia, la limitación de movimiento, así como el evitar la propagación y el contagio del virus, pueden ser algunas de ellas ${ }^{46}$. Apuntamos, además, que la edad que se exige (mayor de dieciséis años) atiende a una razón de supervivencia de las personas más jóvenes, las cuales tienen una mayor esperanza de vida. Teniendo en cuenta que el código civil fue redactado en 1889, en esta época la esperanza de vida no se estimaba tan alta como en la actualidad, de ahí que se rebajara la mayoría de edad (la cual también ha sufrido cambios con las modificaciones legislativas, ya que antes era a los 21 años, y en la Constitución española se estableció en los 18 años cumplidos).

Respecto a la necesidad de firma o no de testador y testigos, el artículo 701 c.c. no indica nada al respecto. Pero no podemos olvidar que nos encontramos ante un testamento abierto, una modalidad de otorgamiento de dicho testamento, en la que no interviene el notario, y se precisa un número de testigos superior al del testamento abierto ante notario (en los casos en que se requiera la concurrencia de los mismos), además de rebajarse la edad para ser testigo, que en la situación de testamento abierto ante notario se precisa la mayoría de edad, y en caso de epidemia se admite que se menor de edad, pero mayor de dieciséis años, como hemos indicado en un punto anterior del presente trabajo.

Pero entonces, teniendo en cuenta lo indicado en el artículo 679 c.c., en el que se define qué es un testamento abierto, señalando que será abierto el testamento "siempre que el testador manifiesta su última voluntad en presencia de las personas que deben autorizar el acto, quedando enteradas de lo que en él se dispone", y que el artículo 695 c.c. indica:

45 Real Academia Española, s.v. "procurar", [en línea], 2020, disponible en: https://dle.rae. es/?w=procurar [consultado el 8 de abril de 2020].

46 Ripoll, A., "Testamentos en caso de epidemia y en peligro de muerte", cit., 5. 
El testador expresará oralmente o por escrito su última voluntad al notario. Redactado por éste el Testamento con arreglo a ella y con expresión del lugar, año, mes, día y hora de su otorgamiento y advertido el testador del derecho que tiene a leerlo por sí, lo leerá el notario en alta voz para que el testador manifieste si está conforme con su voluntad. Si lo estuviere, será firmado en el acto por el testador que pueda hacerlo y, en su caso, por los testigos y demás personas que deban concurrir.

Si el testador declara que no sabe o no puede firmar, lo hará por él y a su ruego uno de los testigos.

Hay que atender también a lo dispuesto en el artículo 25 de la Ley Orgánica del Notariado y en los artículos 167 a 169 y 193 a 196 del Reglamento de la Organización y Régimen del Notariado.

Parece, pues, que tenga que ser firmado por el testador y los testigos, pero hay que considerar que el artículo 702 c.c. indica que sería válido aunque no se escriba, pero dice, en realidad, literalmente "aunque los testigos no sepan escribir". Parece deducirse que los que tengan que escribir el testamento sean los testigos, y no el testador, pero en aplicación del artículo 695 c.c. sería firmado por el testador y testigos, o solamente por estos, si el testador no sabe o no puede, a pesar de que el precepto solo hace referencia a la redacción del documento, pero no a la firma.

La sTs de 2 de julio de 1977 (RJ 1977\3256), en un supuesto de testamento en peligro inminente de muerte, aunque el artículo 702 c.c. se aplica tanto al testamento en caso de epidemia como al testamento otorgado si el testador se hallare en peligro inminente de muerte, indicó:

Que lo verdaderamente excepcional de este testamento resalta cuando según el art. 702 no sea posible escribirlo, a pesar de lo cual será válido, pudiendo proceder esa imposibilidad de dos causas diferentes: Primera: Cuando por la urgencia del caso no pueda escribirse en el mismo momento del otorgamiento, o por no tener en tal acto los elementos necesarios para hacerlo, lo que no impide que los testigos con posterioridad, y con la mayor brevedad posible, consignen por escrito las manifestaciones que el testador les hizo y lo suscriban con su firma; y Segunda: Cuando los testigos no sepan escribir y, entonces, al no poder consignar en esta forma, tendrán que conservar en la memoria las manifestaciones del testador, hasta el momento de hacer su declaración ante el Juez, para su elevación a escritura pública y protocolización (...) no cabiendo prescindir de la formalidad de la escritura, sino en el caso extremo de imposibilidad material, para impedir que pueda falsearse la voluntad del testador por medio de confabulaciones ulteriores, que pongan en peligro su autenticidad, siendo nulo si fue posible escribirlo y no se escribió.

En el mismo sentido se manifestó la sts de 4 de octubre de 1957 (RJ 1957 2845). Y, como advirtió la sTs de 8 de febrero de 1963 (RJ 1963\785): 
... ni el art. 700 ni el 702 prohíbe la concurrencia al acto de persona distinta a los testigos ni tampoco es cierto que éstos ejerzan la función de Notario y que forzosamente hayan de escribir el documento, como claramente se lee en los textos puesto que la razón o fundamento de esta forma testamentaria radica en dar mayores facilidades por la situación extraordinaria para los que está prevista esta clase de testamento excepcional.

También habría que indicar que al ser oral, se excluiría la posibilidad de otorgar un testamento cerrado ante los testigos indicados en caso de epidemia, y solo sería posible admitir un testamento escrito del testador en el caso de que sea ológrafo, que no precisa tampoco testigos, pero sí que deba ser escrito por el testador mismo, según lo indicado por el artículo 678 c.c., así como por el artículo 688 ibídem, que además precisa una serie de condiciones muy restrictivas, como veremos más adelante.

Otra cuestión que se plantea es si se puede dar simultáneamente la situación de poder testar en peligro inminente de muerte y en caso de epidemia. La respuesta es positiva. En caso de epidemia se puede testar tanto por el testamento propiamente indicado para dicha situación como por el que corresponde por hallarse el testador en peligro inminente de muerte. Situación que a la inversa no se produce, ya que, por supuesto, no siempre que se halle el testador en peligro inminente de muerte se encontrará ante un caso de epidemia.

La diferencia entre uno y otro tipo de testamento, como hemos indicado, radica en el número de testigos, que en el caso de inminente peligro de muerte es de cinco. La pregunta es si se está en dicha situación, cuál sería la elección, desde luego por el número de testigos, sería el testamento en caso de epidemia, que precisa un número menor de testigos, y además de menos edad que el de inminente peligro de muerte. Ya que la excepción de la edad solo se contempla en el artículo 701 c.c., en relación con el artículo 681 ibídem.

\section{Las nuevas tecnologías de la información y la comunicación (TICs) y su aplicación al testamento en caso de epidemia}

A continuación nos ocuparemos de algunas cuestiones relacionadas con las nuevas tecnologías de la información y la comunicación (TICS) en cuanto al otorgamiento del testamento en caso de epidemia.

El testamento en caso de epidemia se indica que se otorgará "ante tres testigos", lo cual plantea diversas situaciones, en particular si puede ser de forma síncrona o asíncrona con la manifestación de voluntad del testador. Pensemos en el caso de las personas hospitalizadas que no tienen las mismas opciones que las que no lo están; de ahí la importancia de los medios electrónicos.

Si se trata de concurrencia sincrónica de los testigos, se podría utilizar un ordenador, una tablet o smartphone, con diferentes programas informáticos de videollamada, y en tal caso el testamento sería considerado válido, ya que no se indica en el 
precepto que la presencia deba ser física, por lo que podrá acudirse a una presencia virtual. De hecho, en tiempo de epidemia es más que recomendable que no haya contacto entre las personas, para evitar el contagios y la propagación del virus.

En el caso de una comunicación asíncrona, podría realizarse a través de diversas conexiones, ya que el precepto no hace referencia a la unidad de acto, aunque nos encontraríamos con lo indicado en el artículo 679 c.c., que alude a la presencia de las personas que deben autorizar el acto, y en el artículo 699 c.c., que hace referencia a las formalidades que se "practicarán en un solo acto que comenzará con la lectura del testamento, sin que sea lícita ninguna interrupción, salvo la que pueda ser motivada por algún accidente pasajero".

Por otra parte, se indica que el testamento se escribirá, y la duda se plantea respecto de si esa escritura ha de ser manuscrita (como sucede con el testamento ológrafo, tal y como dispone el artículo 688 c.c.) o puede realizarse por medios electrónicos. Lo anterior por cuanto la norma no indica el soporte de la escritura.

En el caso de que no se pueda escribir, se sugiere que puede ser oportuno grabar la voluntad del testador, ya que confiar en la memoria de los testigos puede no dar garantías suficientes de que luego sean capaces de recordar exactamente, siendo posible incluso llegar a dudar de la veracidad de lo atestiguado por estos.

Resulta extraño que el artículo 702 c.c. emplee, sin que haya sido todavía suprimida, la expresión "los testigos no sepan escribir". Según la definición de la Real Academia Española, "analfabeto" es "el que no sabe leer ni escribir" 47 , pero aquí se refiere solo a que no sepan escribir (no se dice nada de si saben o no leer), con lo que se está refiriendo a los ágrafos, que según la definición de la Real Academia Española es el que "es incapaz de escribir o no sabe hacerlo" 48 . Entonces, pueden ser testigos aunque no sepan escribir, si bien se indica que se escribirá el testamento, en caso de ser posible. Pero la cuestión es que si los testigos no saben escribir (en los tiempos actuales es difícil que haya tres personas que no sepan escribir), lo tendría que escribir un tercero que no haya sido testigo. Se trata de una incongruencia que persiste en el texto legal ${ }^{49}$.

Aquí se plantearía la cuestión de si sería válida o no la firma electrónica. La Ley 10/2008, aplicable a Cataluña, menciona en su artículo 421-14 la firma electrónica y la redacción en soporte electrónico del testamento cerrado ${ }^{50}$.

Respecto de la posibilidad de que el testador deje su última voluntad a través de medios analógicos o digitales, establece el artículo 64.3 de la Ley Orgánica, de 28

47 Real Academia Española, s.v. "analfabeto/a", [en línea], 2020, disponible en: https://dle.rae. es/?w=analfabeto [consultado el 8 de abril de 2020].

48 Real Academia Española, s.v. "ágrafo/fa”, [en línea], 2020, disponible en: https://dle.rae. es/?w=\%C3\%A1 grafo [consultado el 8 de abril de 2020].

49 López-Galiacho, J., "La 'rabiosa' actualidad del testamento en caso de epidemia", cit., 5.

50 RAmón, F., "Última voluntad digital, testamento digital, heredero digital: el mundo virtual de la transmisión hereditaria en el derecho español", Revista de Privacidad y Derecho Digital, vol. 4, n. ${ }^{\circ}$ $14,2019,82$. 
de mayo de 1862 , que se refiere a la presentación, adveración, apertura y protocolización de los testamentos otorgados en forma oral, que a la solicitud "se acompañará la nota, la memoria o el soporte en el que se encuentre grabada la voz o el audio y el vídeo con las últimas disposiciones del testador, siempre que permita su reproducción y se hubieran tomado al otorgarse el testamento". La permisión de la grabación de la última voluntad soluciona el supuesto de fallecimiento de todos los testigos ${ }^{51}$.

\section{Propuesta de regulación del testamento en caso de epidemia por parte de la Asociación de Profesores de Derecho Civil de España}

La regulación actual del código civil español del testamento en caso de epidemia, a pesar de considerarse este como una figura de poca aplicación, no ha sido óbice para que la figura se mantenga en una propuesta de código civil que se elaboró por parte de la Asociación de Profesores de Derecho Civil de España.

Se contemplaba su regulación en el Libro Cuarto "De los modos de adquirir la propiedad", en el Título vi "De las Sucesiones", en el Capítulo II "De la sucesión testamentaria”, dentro de la Sección 5. a dedicada al testamento abierto ${ }^{52}$.

Se distinguen allí dos tipos de testamentos, el común y el especial. El común puede revestir la forma ológrafa, abierta o cerrada. Como especiales se incluyen el militar, el marítimo y el hecho en país extranjero.

El testamento en caso de epidemia, que se propone en el artículo 462-32, no es un testamento especial, sino una modalidad de testamento abierto, sin intervención de notario y ante tres testigos mayores de dieciséis años.

Difiere del testamento en peligro inminente de muerte, que se contiene en la propuesta en el artículo 462-31, en que el testador debe hallarse en peligro inminente de muerte, y se precisa de cinco testigos idóneos, sin necesidad de notario, siempre que no sea posible su asistencia.

En el testamento en caso de epidemia no es preciso que el testador se encuentre en peligro inminente de muerte, sino que se encuentre en una situación declarada de epidemia, precisamente por las dificultades de otorgarse testamento ante notario por las restricciones a la circulación de las personas.

Tanto el testamento en caso de epidemia como el otorgado en peligro inminente de muerte, como establece la propuesta del artículo 462-33, se escribirá, de ser ello posible; si no lo fuera, también valdrá el testamento. Aquí habría que hacer referencia a qué soportes serían admisibles en este tipo de testamento, teniendo en cuenta que no se precisa quién debe escribir el testamento, si el otorgante o si los testigos, como tampoco los requisitos para la escritura, si debe contener la fecha, si debe ser

51 Ripoll, A., "Testamentos en caso de epidemia y en peligro de muerte", cit., 5.

52 Martínez, P., "Título vi. Capítulo ir. Secciones 3. a a 9.", [en línea], en Propuesta de código civil, Madrid, Tecnos, 2018, 554 ss., disponible en: http://www.derechocivil.net/images/libros/obra_completa.pdf [consultado el 7 de abril de 2020]. 
firmado por el testador y los testigos. Por analogía, se podría aplicar lo indicado para el testamento ológrafo, que debe cumplir una serie de requisitos para su validez.

Tal y como contempla la propuesta del artículo 462-30, las formalidades deben practicarse en un solo acto que se inicia con la lectura del testamento, no siendo lícita ninguna interrupción, salvo la que se motive por algún accidente pasajero.

Se contempla la caducidad de los tipos testamentarios indicados, tanto el testamento en caso de epidemia como el realizado en caso de encontrarse en peligro inminente de muerte, en la propuesta del artículo 462-34, que quedaría ineficaz si pasan dos meses desde que el testador ha salido del peligro de muerte; nótese que aquí no se hace mención al concepto de inminente, o desde que haya cesado la epidemia. Concepto ambiguo, que no queda claro si es cuando han cesado los contagios, se ha levantado el estado de alarma, o si se ha producido la curación de todos los afectados.

En el caso de que se produzca el fallecimiento de la persona que ha testado durante el plazo, el testamento quedará ineficaz igualmente si dentro de los tres meses siguientes al fallecimiento no se acude al notario para su elevación a escritura pública, ya se haya otorgado por escrito o de forma verbal, en el caso de que no pudiera trasladarse la voluntad del testador por escrito.

Los testamentos que se otorgan ante testigos y sin la autorización de un notario son ineficaces si no se elevan a escritura pública y se protocolizan según indica la legislación notarial, como señala la propuesta del artículo 462-35.

\section{Otros tipos de testamento que se pueden otorgar en la situación de epidemia}

No es nuestra intención realizar un estudio exhaustivo sobre estas tres formas de testamento común, ya que excedería los límites del presente trabajo, sino, simplemente, indicar otras opciones que tiene el testador en caso de epidemia, además del analizado que propiamente se da precisamente cuando hay una epidemia, y los cuatro restantes (abierto, cerrado, ológrafo y en peligro inminente de muerte) que se pueden otorgar en cualquier situación, tanto en caso de epidemia como en caso de que no la haya.

A lo largo del trabajo nos hemos referido a ellos, con más detalle para unas formas que para otras, por lo que solo vamos a incidir en los aspectos más relevantes, sin pretensión de abordar todos los problemas que podrían llegar a plantearse.

Antes de entrar de lleno en las formas comunes admitidas por el artículo 676 c.c., ológrafo, abierto y cerrado, y el testamento en peligro inminente de muerte, recogido en el artículo 700 c.c., debemos referirnos a la regulación que se ha realizado por la Ley Orgánica 3/2018, de 5 de diciembre, de protección de datos personales y garantía de los derechos digitales ${ }^{53}$, en cuyo artículo 96, bajo la desafortunada deno-

53 BOE, 294, de 6/12/2018, [en línea], disponible en: https://www.boe.es/buscar/doc.php?id=BOEA-2018-16673 [consultado el 7 de junio de 2020]. 
minación de "testamento digital", se regula el acceso a contenidos gestionados por prestadores de servicios de la sociedad de la información sobre personas fallecidas.

Ello no es un testamento en el sentido que estamos analizando, ya que no contiene ni los requisitos de otorgamiento y de validez para ser considerado como tal, sino que simplemente se refiere al acceso a contenidos del denominado patrimonio digital.

Otorgar testamento a través de plataformas on-line o plataformas digitales no es posible, por lo que al denominar la Ley Orgánica 3/2018 “testamento" a lo que no lo es, le hace un flaco favor.

De igual modo, cuando la Ley 10/2017, de 27 de junio, de las voluntades digitales y de modificación de los libros segundo y cuarto del código civil de Cataluña ${ }^{54}$, hace referencia a la voluntad digital, no se refiere a un testamento, sino a la disposición del patrimonio digital, que es diferente a la forma de otorgamiento, ya que se refiere al contenido, y no a la forma de otorgarse un testamento.

\section{A. Testamento abierto y cerrado notarial}

Se regula en los artículos 694 a 705 c.c. el testamento abierto ${ }^{55}$, y en los artículos 706 a 715 c.c. el testamento cerrado ${ }^{56}$. Ambos son formas del testamento común.

En el caso de epidemia las posibilidades de otorgar un testamento abierto o cerrado ante notario están más limitadas que en una situación normal, ya que, por las razones que hemos indicado anteriormente, está restringida la libertad de circulación, con la finalidad de no producir una expansión del contagio.

En todo caso, dependerá del notario, ante la solicitud del testador, valorar la situación y decidir si está ante un caso en que pueda atender la petición.

Esta forma de testar se caracteriza, en líneas generales, por la presencia del notario y de dos testigos idóneos que deben concurrir al otorgamiento, pero solo en los casos siguientes que determina el artículo 697 c.c.:

1. ${ }^{\circ}$ Cuando el testador declare que no sabe o no puede firmar el testamento.

54 BOE, 173, de 21/07/2017, [en línea], disponible en: https://www.boe.es/buscar/doc.php?id=BOEA-2017-8525 [consultado el 7 de junio de 2020].

55 Véase sobre ello Martos, M. A., Las solemnidades del testamento abierto notarial, Granada, Comares, 1999, 25; RoDríGUEZ, A., "El tratamiento de las nulidades formales del testamento abierto", Anales de la Real Academia de jurisprudencia y legislación, n. 37, 2007, 549-578; Domingo, A., "De algunas paradojas en el testamento abierto o de la necesidad de suprimir sus testigos", Boletín de Información del Ilustre Colegio Notarial de Granada, n. ${ }^{\circ}$ 126, 1991, 1666-1670.

56 Más ampliamente sobre los preceptos, RodríGuEZ, A., "La apertura del testamento abierto: notas de historia”, en Cabanillas, A. (coord.), Estudios jurídicos en homenaje al profesor Luis Díez-Picazo, vol. 4, 2002, Madrid, Civitas, 5497-5512; De CAStro, J., "En defensa del testamento cerrado", en DE Andrés, C. y Hernández, G. (coords.), Diez años de Abogados de familia, Madrid, Wolters Kluwer, 2003, 39-42; IruRzun, D., "De nuevo sobre el testamento cerrado (testamento cerrado, testamento en formación)", Revista Jurídica del Notariado, n. '100-101, 2017, 373-379. 
2. ${ }^{\circ}$ Cuando el testador, aunque pueda firmarlo, sea ciego o declare que no sabe o no puede leer por sí el testamento.

Si el testador que no supiese leer fuera enteramente sordo, los testigos leerán el testamento en presencia del notario y deberán declarar que coincide con la voluntad manifestada.

3. ${ }^{\circ}$ Cuando el testador o el notario lo soliciten.

El testador podrá expresar su última voluntad al notario de forma verbal o mediante escrito. El notario redactará el testamento siguiendo la última voluntad que le ha manifestado el testador, con expresión del lugar, año, mes, día y hora. El testador tiene derecho a leer el testamento elaborado por el notario. En el caso de lectura por parte del notario, el testador manifestará si está conforme con la voluntad indicada, y se firmará en el acto por el testador, si puede hacerlo, y, en su caso, por los testigos y demás personas que deban concurrir.

En el caso de que el testador no sepa o no le sea posible la firma, lo hará por él y a su ruego uno de los testigos.

El notario dará fe de conocer al testador o de haberlo identificado debidamente, teniendo en cuenta lo indicado en el artículo 686 c.c., y deberá constar que el testador goza de la capacidad legal necesaria para el otorgamiento.

Todas las formalidades se practicarán en un solo acto que empezará con la lectura del testamento, sin ser lícita ninguna interrupción, salvo la motivada por algún accidente pasajero, como indica el artículo 699 c.c.

El testamento cerrado se realizará por escrito, permitiéndose los medios mecánicos, con los requisitos del artículo 706 c.c. (firma del testador en todas las hojas y al final), y también puede ser manuscrito (firma del testador al final).

Se observarán las solemnidades que indican el artículo 707 y siguientes, y se contemplan las distintas situaciones en que el testador no puede expresarse verbalmente pero sí escribir. El testamento se podrá conservar en poder del testador, encomendarse su guarda a un tercero o depositarse en poder del notario.

Posteriormente se indican en el artículo 712 las actuaciones una vez fallecido el testador.

En cuanto a las solemnidades, la SAP de Guipúzcoa, Sección 2. a , de 2 de junio de 1998 (AC 1998\1600), consideró que la solemnidad como requisito intrínseco de los testamentos significa que su ausencia, ya sea total o parcial, pero siempre esencial, conlleva la ineficacia de la declaración informalmente manifestada. Alude a lo anterior la sTs de 25 de abril de 1991 (RJ 1991\3029), que consideró:

... la forma es así requisito 'ad solemnitatem' y no 'ad probationem', afecta a la propia sustancia del negocio, que si no se ajusta a ella no llega a nacer, según el tan conocido principio de 'dat esse rei' y ni aun acreditándose más tarde que tal era la 
auténtica voluntad del testador cabe concederle efecto alguno, pues voluntad y forma de expresión marcada por la Ley forman una unidad indisoluble, de imposible disociación.

La sTs de 21 de junio de 1986 (RJ 198613788), a su turno, indica:

... para la validez de todo testamento, es de absoluta necesidad que se cumplan de manera rigurosa todas las solemnidades esenciales y requisitos establecidos en la normativa contenida en el art. 695 del Código Civil, que establece los requisitos de orden formal que determinan la validez del testamento abierto, inobservancia de formalidades que determina, conforme el art. 687 del Código Civil que proclama, la nulidad de la disposición testamentaria.

En el mismo sentido se pronuncian las SsTs de 10 de julio de 1944 (RJ 1944\911), de 28 de octubre de 1965 (RJ 1965\4747), de 27 de septiembre de 1968 (RJ 1968\5163) y de 9 de mayo de 1990 (RJ 1990\3695).

\section{B. Testamento ológrafo}

Esta forma está regulada en los artículos 688 a 693 c.c., y ha planteado numerosos problemas en el ámbito doctrinal respecto a los requisitos para su validez, siendo una de la formas más complejas. Debe estar escrito todo él y firmado por el testador, con expresión del año, mes y día en que se otorgue. Si contuviere palabras tachadas, enmendadas o entre renglones, las salvará el testador bajo su firma.

No se admiten medios mecánicos para ser otorgado. Los soportes en que se ha admitido un testamento ológrafo son una carta, una tarjeta de visita ${ }^{57}$, tela, madera y cartón, inclinándose la doctrina por que sea papel ${ }^{58}$. Y se excluyen todos los medios fonográficos y audiovisuales, por requerirse que sea por escrito.

Una vez producido el fallecimiento, debe ser presentado ante el notario por la persona que lo tenga en su poder, y se procederá a adverarlo y protocolizarlo.

Esta modalidad permite a los sujetos de vecindad civil cuya regulación no les permite realizar el testamento en caso de epidemia, otorgar esta forma cuando se encuentren en dicha situación. Es el caso del artículo 421-5.3 de la Ley 10/2008, que no permite a las personas con vecindad civil catalana otorgar testamento exclusivamente ante testigos (como es el de en caso de epidemia), por lo que podrán otorgarlo, si no pueden hacerlo abierto o cerrado, en forma ológrafa.

57 RAmón, F., "Última voluntad digital, testamento digital, heredero digital: el mundo virtual de la transmisión hereditaria en el derecho español", cit., 83.

58 Torres, T. P., El testamento ológrafo, Madrid, Montecorvo, 1977, 35. 


\section{Testamento en peligro inminente de muerte}

Hemos hecho referencia anteriormente a este tipo de testamento abierto y oral, sin necesidad de presencia de notario, y que se regula en el artículo 700 c.c. Se trata también de un testamento efímero como el otorgado en caso de epidemia.

Se precisará la presencia de cinco testigos idóneos. La doctrina discute qué se puede entender por "inminente peligro de muerte" 59 . Hay que pensar en los casos de hospitalización, por lo que aunque no se precisa dictamen médico, sí se requiere la intervención de facultativo indicando la situación del paciente, la situación física del mismo y las evidencias que pueden determinar la situación de inminente posibilidad de fallecimiento ${ }^{60}$. Pero, no se limitaría solo a esos supuestos de localización hospitalaria, sino que también podría producirse en otro escenario diferente en el que el sujeto perciba, al igual que los testigos, que está en una situación de riesgo de fallecer ${ }^{61}$. Por ejemplo, se piensa en situaciones de afecciones en las que el sujeto no está hospitalizado pero su estado se ha agravado considerablemente y se teme que va a fallecer.

La jurisprudencia se ha pronunciado sobre este testamento y sus requisitos. Así, la SAP Guipúzcoa, Sección 2. ${ }^{\text {, }}$, de 2 de junio de 1998 (AC 1998\1600), precisó que el testador se tenía que hallar en peligro inminente de muerte, no bastando, por consiguiente, que se otorgue en estado de enfermedad grave, sino en circunstancias urgentes y extremas de peligro racional e inmediato de perder la vida el testador; que solo en el caso de imposibilidad de concurrencia de notario cabe prescindir de él, que la imposibilidad de esta ha de ser apreciada con criterio amplio (sTs de 19 de diciembre de 1959 [RJ 1959\4890]), y la necesidad de otorgamiento ante cinco testigos idóneos. Es precisa, como aludió la sts de 4 de febrero de 1943 (RJ 1943\126), la asistencia de todos los testigos, por lo que "no habiéndose probado la asistencia al acto de uno de los testigos, queda incumplido con ello uno de los requisitos más esenciales del testamento de que se trata. Por lo que no concurre uno de los elementos esenciales del mismo". En el mismo sentido se pronuncian el Auto Audiencia Provincial de Madrid, Sección 21 . , de 28 de marzo de 2011 (AC 2011 1478), la SAP de Lugo, Sección Única, de 25 de enero de 2000 (AC 2000\3005), y las ssts de 27 de junio de 2000 (RJ 2000\5910) y de 10 de junio de 2005 (RJ 2005\4365), en cuanto a que procederá este testamento siempre que exista peligro real de inminencia de muerte del testador.

59 Véase Rivas, J. J., “Artículo 700. Peligro de muerte”, en Valpuesta, R. (coord.), Cañizares, A., De Pablo, P. y Orduña, F. J. (dirs.), Código civil comentado. Libro ili: De los diferentes modos de adquirir la propiedad (artículos 609 a 1087), cit., 460-468.

60 Ripoll, A., "Testamentos en caso de epidemia y en peligro de muerte", cit., 3.

61 SÁEnz, A., "El testamento del Rey Católico y la legítima aragonesa”, Revista de Derecho Civil Aragonés, n. ${ }^{\circ} 21-22,2015-2016,157$. En este trabajo se muestra la diferencia entre inminente peligro de muerte y persona que padece enfermedad muy grave, diferenciándolo, en este caso en relación con el Rey Fernando el Católico. 
La sTs de 2 de julio de 1977 (RJ 1977\3256) admitió que era suficiente la prueba de que no se pudo encontrar al notario o era difícil obtener su concurrencia. Y en el mismo sentido se manifiesta la sTs de 19 de diciembre de 1959 (RJ 1959\4416).

Se aplicará lo indicado en los artículos 681 y 682 c.c. respecto a las condiciones para ser testigo en el testamento, con la salvedad de que en este caso los testigos deberán ser mayores de edad, ya que la minoría de edad pero mayoría de 16 años solo se admite en el testamento en caso de epidemia (art. 681 c.c., a sensu contrario).

Como señala el artículo 685 c.c., los cinco testigos estarán obligados a conocer al testador (no se refiere el precepto a que lo identifiquen) ${ }^{62}$ y procurarán asegurarse de su capacidad, y de conformidad con el artículo 663, estarán incapacitados para testar, también bajo esta modalidad, los menores de catorce años y el que habitual o accidentalmente no se hallare en su cabal juicio. Sobre la capacidad, puede verse la SAP Ourense de 2 de diciembre de 2002 (AC 2002\2241).

A diferencia del testamento en caso de epidemia del artículo 701 c.c., que se refiere a "sin intervención de notario", en este caso, el artículo 700 c.c. hace mención a "sin necesidad de notario". Consideramos que la situación difiere en las características de uno y otro, ya que en el primer caso parece referirse a las dificultades de poder hacerse ante notario, precisamente por las medidas adoptadas en el tiempo de epidemia, por ejemplo, el confinamiento de la población, mientras que en el segundo caso se puede contemplar el supuesto de que no haya notaría que se pueda localizar de forma inmediata, o riesgo de que no llegue a tiempo el notario, por el riesgo de inminente peligro de muerte ${ }^{63}$.

Si bien es cierto que el testamento en caso de epidemia no significa que el testador se encuentre en peligro inminente de muerte, sino que precisamente por la duración de dicha situación -la epidemia- sea su voluntad otorgar testamento por diversas razones.

Precisa esta modalidad de testamento que se escriba, si ello es posible, pero es válido aunque los testigos no sepan escribir. Tal y como indica el artículo 681 c.c., no se precisa que los testigos tengan que saber leer y escribir, ya que solo excluye a los que "no entiendan el idioma del testador".

En cuanto al soporte donde deba escribirse el testamento, se plantea también el mismo problema que en el testamento en caso de epidemia, en cuanto al soporte, ya que no se indica de forma expresa si el testamento debe escribirse en un soporte específico o se valdría cualquier tipo de soporte, incluso un soporte en el que se escribiera de forma no manuscrita, teniendo en cuenta las nuevas tecnologías de la información y la comunicación.

62 Ripoll, A., "Testamentos en caso de epidemia y en peligro de muerte", cit., 3.

63 Ripoll, A., "Testamentos en caso de epidemia y en peligro de muerte", cit., 3, señala "Que no sea razonablemente posible, por motivos de máxima urgencia, localización o inexistencia de notaria demarcada, la presencia notarial y es que este testamento es un recurso extraordinario y subsidiario al testamento notarial abierto o cerrado, no otra cosa quiere decir la expresión 'sin necesidad de notario"". 
Como todo testamento posterior que se otorgue, ya sea abierto, cerrado u ológrafo, esta modalidad de testamento en peligro inminente de muerte puede revocar un testamento anterior ${ }^{64}$.

Como indica el artículo 703 c.c., quedará ineficaz si pasan dos meses desde que el testador ha salido del peligro de muerte (nótese que en este precepto no se habla de inminente). Consideramos que es una redacción que podría haberse mejorado, porque hubiera sido deseable que se mantuviera la indicación de "inminente", ya que en peligro de muerte se puede considerar como una situación que puede afectar a un sujeto pero sin que sea inminente que se produzca el fallecimiento.

También queda ineficaz si se produce el fallecimiento y dentro de los tres meses siguientes al mismo no se acude al notario para elevarlo a escritura pública, tanto si se hubiera otorgado por escrito como si lo hubiera sido de forma oral. No se indica quiénes deben acudir al notario, si son los testigos, los posibles herederos, los parientes del fallecido.

Los territorios forales también disponen de esta forma testamentaria, y destacamos por su peculiaridad la Ley $5 / 2015$, mencionada anteriormente ${ }^{65}$, que regula en su artículo 23 el testamento en peligro de muerte o "hilburuko":

1. El que, por enfermedad grave u otra causa, se halle en peligro inminente de muerte, podrá otorgar testamento ante tres testigos idóneos sin intervención de notario y sin necesidad de justificar la ausencia de fedatario público. Este es el testamento que en lengua vasca se denomina "hilburuko".

2. No será necesario redactar por escrito el testamento y leerlo al testador cuando no lo permita la urgencia del caso, pero, una vez haya declarado con palabras dispositivas su última voluntad, se escribirá lo antes posible.

3. Este testamento quedará ineficaz si pasasen dos meses desde que el testador haya salido del peligro de muerte. Si el testador falleciese en dicho plazo, quedará también ineficaz el testamento si no se presenta para su adveración y elevación a escritura pública en la forma prevenida en las leyes procesales dentro de los tres meses siguientes al fallecimiento.

64 La casuística puede ser diversa. Véase FernándEZ, R., “Testamento en inminente peligro de muerte y testamento en vascuence”, en Martínez-Simancas, J. y Bercovitz-Rodríguez-CANo, R. (coords.), Derechos civiles de España, Madrid, Sopec, 2000, 4459-4472; RodríguEz, M. "E., "Validez del testamento en inminente peligro de muerte y revocación del testamento notarial anterior: comentario a la sTs 10 junio 2005 (RJ 2005, 4365)", Revista Aranzadi de Derecho Patrimonial, n. ${ }^{\circ}$ 16, 2006, 403412; FERnÁNDEZ, J. I., "Nulidad de testamento otorgado en inminente peligro de muerte (comentario a la sentencia del Tribunal Supremo de 27 de junio de 2000", Actualidad civil, n. ${ }^{\circ}$ 2, 2002, 657-668. 
4. En caso de que, habiendo salido el testador del peligro de muerte, quede incapacitado para otorgar un nuevo testamento, el plazo para la adveración y la elevación a escritura pública será de tres meses contados desde aquel primer instante.

5. Adverado judicialmente un testamento se procederá a su protocolización notarial.

\section{Conclusiones}

En los tiempos que estamos viviendo, por desgracia únicos y esperemos que irrepetibles, con una pandemia mundial por coronavirus (Covid-19), se ha rescatado, de forma totalmente inesperada, una figura jurídica, calificada por muchos como momia jurídica.

Un testamento al que hubiera sido impensable dedicarle una atención detallada en otras circunstancias, y al que precisamente por la pandemia le hemos dedicado este trabajo. Es el testamento en caso de epidemia, un testamento que hemos denominado efímero, ya que su validez está supeditada a un plazo concreto, ya cese la epidemia, ya fallezca el testador en dicho plazo, si no se acude al notario en el plazo indicado. Por tanto, presenta unas características muy peculiares, en consonancia con la situación que debe producirse para su otorgamiento.

Una rareza que ha pervivido en el código civil, y que apenas había sido aplicada en la práctica. Prueba de ello es que la legislación posterior al código civil, la referente a los territorios de derecho foral, no lo contempla, salvo alguna excepción, aunque se remita al código civil, o se aplique este como supletorio. O incluso que no permitan un testamento solo ante testigos, con lo que eliminan este testamento en caso de epidemia, incluso como supletorio. Es el caso del código civil de Cataluña.

No obstante, hay que indicar que en la Propuesta de código civil que se elaboró por parte de la Asociación de Profesores de Derecho Civil de España se mantiene y se contempla en una futura regulación. Sin embargo, en dicha regulación se echa en falta que se indique el soporte, dado que en un futuro código civil en un mundo digitalizado sería de interés contemplarlo.

De un precepto, el artículo 701 c.c., que apenas tiene dos líneas, destacando por su parquedad, junto con los artículos 702 y 703 c.c., se plantean numerosos problemas en un escenario que difiere sustancialmente del que tuvo el precepto cuando fue redactado originariamente, el año 1889, y que fue modificado en el año 1958, pero con una breve supresión por razón de sexo, manteniéndose el espíritu del precepto.

Y precisamente el escenario difiere porque en el siglo XXI nos encontramos inmersos en las nuevas tecnologías de la información y la comunicación (TICs), en las que los dispositivos electrónicos se aplican en muchos de los actos que realizamos: contratación electrónica, documentación, geolocalización, entre otros.

Sin embargo, estamos en sede de sucesiones, un ámbito jurídico que sigue siendo reticente al uso de las Tics. Así por ejemplo, un testamento ológrafo no se puede realizar por medios electrónicos, sino que debe ser escrito todo él y firmado por el 
testador, de su puño y letra. Ni que decir tiene que la firma electrónica no se admite tampoco, y sería más que dudosa su admisión en el caso del testamento en caso de epidemia. La falta de informatización de la sucesión en el derecho español conlleva esta serie de problemas, en los que los avances de la técnica no son aplicable a las instituciones decimonónicas, con la salvedad de lo indicado en el código civil de Cataluña para el caso del testamento cerrado.

Pero, en el caso de epidemia, se plantea si ese testamento que se otorga en dicha situación crítica puede verse, dijéramos, complementando con las nuevas tecnologías, tanto en su aplicación de los testigos como del propio testador. Grabar la última voluntad del testador, y la presencia de los testigos a través de videoconferencia, serían unas de las posibilidades.

A ello se une que por esa falta de regulación de la utilización de medios tecnológicos en una sociedad altamente tecnológica no se pueda hacer uso de las Tics, precisamente por no contemplarse en los preceptos.

El denominado "testamento digital" al que hace referencia la Ley Orgánica 3/2018, en su artículo 96, no es un testamento como tal, y es un error del legislador denominarlo así, ya que induce a confusión en la interpretación del precepto. Se hace referencia al acceso a contenidos gestionados por prestadores de servicios de la sociedad de la información sobre personas fallecidas. Se refiere, pues, a una suerte de inventario del contenido. Por tanto, hoy por hoy, no es posible otorgar en el ordenamiento jurídico español un testamento digital.

De igual modo, cuando la Ley 10/2017 hace referencia a la voluntad digital, no se refiere a un testamento, sino a la disposición del patrimonio digital, que es diferente a la forma de otorgamiento, ya que se refiere al contenido y no a la forma de otorgarse el testamento.

La doctrina se ha planteado si en un futuro ello será posible, y la respuesta es dudosa, ya que para ello se tendrían que acometer reformas de gran calado en la normativa que regula el derecho sucesorio español.

Los preceptos que se aplican al testamento en caso de epidemia no están exentos de cuestiones jurídicas de interés: una redacción poco afortunada respecto a los testigos que no sepan escribir, o la supresión del concepto de "idóneos" que sí se precisa para el testamento en peligro inminente de muerte, hacen que la interpretación de los preceptos sea poco clara.

A ello se une la ausencia de una jurisprudencia que haya resuelto supuestos relacionados con esta situación, y que hubiera sido de utilidad para solucionar algunos de los problemas planteados. Ante dicha ausencia, la jurisprudencia que ha resuelto supuestos relacionados con el testamento en peligro inminente de muerte, ya que los artículos 702 y siguientes c.c. se aplican también a este y al testamento en caso de epidemia, se ha pronunciado sobre la posibilidad de escribir el testamento, y sobre la capacidad tanto del testador como de los testigos.

No olvidemos que el testamento para el caso de epidemia solo se aplica precisamente en ese caso: la epidemia, pero no es el único testamento que puede otorgar un 
sujeto en dicha situación, ya que también podrá hacer testamento abierto, cerrado, ológrafo o en peligro inminente de muerte; sin embargo, si necesita otorgar testamento se recomienda que otorgue el contemplado para la situación de epidemia y no los demás, ya que los requisitos son más fáciles de cumplir (tres testigos mayores de dieciséis años), en especial que en el caso del ológrafo, testamento este que no requiere de notario pero que por los requisitos específicos que precisa para su validez puede ser impugnado posteriormente.

\section{Referencias}

Ávila, P., Derecho notarial, Barcelona, Bosch, 1990.

Berrocal, A. I., "La capacidad y voluntad de testar, dos pilares fundamentales en la sucesión testada", Revista Crítica de Derecho Inmobiliario, n. ${ }^{\circ}$ 770, 2018, 3339-3371.

De Castro, J., "En defensa del testamento cerrado", en De Andrés C. y Hernández, G. (coords.), Diez años de Abogados de familia, Madrid, Wolters Kluwer, 2003, $39-42$.

De Lara, M. J., "Epidemia, testamento e historia de las mentalidades: morir de peste en la Huelva del siglo xviI", en Serrano, E. (coord.), Muerte, religiosidad y cultura popular: siglos XIII-XVIII, Zaragoza, Instituto "Fernando el Católico", 393-432.

Domingo, A., "De algunas paradojas en el testamento abierto o de la necesidad de suprimir sus testigos", Boletín de Información del Ilustre Colegio Notarial de Granada, n. ${ }^{\circ} 126,1991,1666-1670$.

FERnÁNDEZ, R., "Testamento en inminente peligro de muerte y testamento en vascuence", en Martínez-Simancas, J. y Bercovitz-Rodríguez-Cano, R. (coords.), Derechos civiles de España, Madrid, Sopec, 2000, 4459-4472.

FERnÁnDEZ, J. I., "Nulidad de testamento otorgado en inminente peligro de muerte (comentario a la sentencia del Tribunal Supremo de 27 de junio de 2000)", Actualidad Civil, n. ${ }^{\circ}$ 2, 2002, 657-668.

IRURZun, D., “Testamentos y pretestamentos: (... 'sin necesidad de Notario'. Artículo 700 CC)", Revista Jurídica del Notariado, n. ${ }^{\circ}$ 69, 2009, 69-146.

IRURZUN, D., "De nuevo sobre el testamento cerrado (testamento cerrado, testamento en formación)", Revista Jurídica del Notariado, n. . 100-101, 2017, 373-379. 
MARTos, M. ${ }^{a}$ A., Las solemnidades del testamento abierto notarial, Granada, Comares, 1999.

RAMón, F., "Última voluntad digital, testamento digital, heredero digital: el mundo virtual de la transmisión hereditaria en el derecho español”, Revista de Privacidad y Derecho Digital, vol. 4, n. ${ }^{\circ}$ 14, 2019, 77-121.

Rodríguez, A., "El tratamiento de las nulidades formales del testamento abierto", Anales de la Real Academia de Jurisprudencia y Legislación, n. . 37, 2007, 549578.

Rodríguez, A., "La apertura del testamento abierto: notas de historia", en CABANILLAS, A. (coord.), Estudios jurídicos en homenaje al profesor Luis Díez-Picazo, vol. 4, 2002, Madrid, Civitas, 5497-5512.

Rodríguez, M. E., "Validez del testamento en inminente peligro de muerte y revocación del testamento notarial anterior: comentario a la sTs 10 junio 2005 (RJ 2005, 4365)", Revista Aranzadi de Derecho Patrimonial, n. . 16, 2006, 403-412.

Romero, A. M., "Testamento e intervalos lúcidos", Actualidad Jurídica Aranzadi, n. ${ }^{\circ} 860,2013,5$.

RIPOLL, A., "Procedimiento notarial de jurisdicción voluntaria: los testigos", Revista Jurídica del Notariado, n. ${ }^{\circ}$ 99, 2016, 551-584.

Rivera, V., “'En caso de epidemia': sentido y alcance de la peculiar locución del artículo 701 CC”, Revista de Derecho Privado, vol. 91, n. . 5, 2007, 81-92.

Rivas, J. J., "Artículo 700. Peligro de muerte”, en Valpuesta, R. (coord.), CañIzares, A., De Pablo, P. y Orduña, F. J. (dirs.), Código civil comentado. Libro iII: De los diferentes modos de adquirir la propiedad (artículos 609 a 1087), Cizur Menor, Thomson Reuters-Civitas, 2011, 460-468.

Rivas, J. J., “Artículo 701. Caso de epidemia”, en Valpuesta, R. (coord.), Cañizares, A., De Pablo, P. y Orduña, F. J. (dirs.), Código civil comentado. Libro III: De los diferentes modos de adquirir la propiedad (artículos 609 a 1087), Cizur Menor, Thomson Reuters-Civitas, 2011, 468-472.

Rivas, J. J., “Artículo 702. Forma testamentaria de los artículos 700 y 701”, en VALpuesta, R. (coord.), Cañizares, A., De Pablo, P. y Orduña, F. J. (dirs.), Código civil comentado. Libro III: De los diferentes modos de adquirir la propiedad (artículos 609 a 1087), Cizur Menor, Thomson Reuters-Civitas, 2011, 472-474. 
SÁENZ, A., "El testamento del Rey Católico y la legítima aragonesa", Revista de Derecho Civil Aragonés, n. ${ }^{\circ}$ 21-22, 2015-2016, 155-172.

\section{Fuentes electrónicas}

Álvarez, V. J., "El coronavirus (Covid-19): respuestas jurídicas frente a una situación de emergencia sanitaria", [en línea], El Cronista del Estado Social y Democrático de Derecho, n. 86-87, 2020, 6-21, disponible en: http://www.elcronista. es/El-Cronista-n\%C3\%BAmero-86-87-Coronavirus.pdf [consultado el 30 de marzo de 2020].

Calaza, C. A., "Los testamentos sin intervención notarial y su eficacia en la "nueva normalidad" ", [en línea], La Ley, n. ${ }^{\circ}$ 9638, 2020, 1-9, disponible en: https://diariolaley.laleynext.es/dll/2020/05/22/los-testamentos-sin-intervencion-notarialy-su-eficacia-en-la-nueva-normalidad [consultado el 6 de junio de 2020].

Comisión Permanente del Consejo General del Notariado, Circular de 18 de marzo de 2020, [en línea], disponible en: https://madrid.notariado.org/portal/ documents/20828/22843/Circular_com_permanente+18_03_20/4021a11f47c6-44ac-b010-caebf1314449 [consultado el 6 de abril de 2020].

Cotino, L., "Confinamientos, libertad de circulación y personal, prohibición de reuniones y actividades y otras restricciones de derechos por la pandemia del coronavirus", [en línea], en La Ley, n. ${ }^{\circ}$ 9606, 2020, 1-20, disponible en: https:// diariolaley.laleynext.es/Content/Documento. $\operatorname{aspx}$ ?params=H4siAAAAAAAEAMtMSbF1ctEAamMDcwtjM7Wy1KLizPw8Wymdi6CYsYFaXn5KaoiLs21pXk pqWmZeagpiswzapUt-ckhlQaptWmJOcapaalJ-fjaKSfEwEwBQINdEYwAAAA= =wKE [consultado el 6 de abril de 2020].

Cotino, L., "Los derechos fundamentales en tiempos del coronavirus: régimen general y garantías y especial atención a las restricciones de excepcionalidad ordinaria", [en línea], El Cronista del Estado Social y Democrático de Derecho, n. ${ }^{\circ}$ 86-87, 2020, 88-101, disponible en: http://www.elcronista.es/El-Cronistan\%C3\%BAmero-86-87-Coronavirus.pdf [consultado el 3 de abril de 2020].

Dirección General de Seguridad Jurídica y Fe Pública, Instrucción 15 de marzo de 2020 sobre la adopción de medidas que garanticen la adecuada prestación del servicio público notarial, [en línea], disponible en: https://ficheros.mjusticia. gob.es/pdf/INSTRUCCI\%C3\%93N\%20DGSJyFP\%2015-03-2020.pdf [consultado el 6 de abril de 2020]. 
Giménez, V. y Ramón, F., "El testamento nuncupativo: del derecho foral a la futura regulación sucesoria valenciana”, [en línea], Revista de Derecho Civil Valenciano, n. ${ }^{\circ}$ 6, 2009, 1-9, disponible en: http://derechocivilvalenciano.com/ revista/numeros/6-segundo-semestre-2009/item/15-el-testamento-nuncupativodel-derecho-foral-a-la-futura-regulacion-sucesoria-valenciana [consultado el 7 de abril de 2020].

López-Galiacho, J., "La 'rabiosa' actualidad del testamento en caso de epidemia", [en línea], Hay Derecho, 2020, 1-14, disponible en: https://hayderecho.expansion.com/2020/03/20/la-rabiosa-actualidad-del-testamento-en-caso-de-epidemia/ [consultado el 8 de abril de 2020].

Lorenzo, M. a D., “Testamento de incapacitado: informe médico”, [en línea], Notarios y Registradores, s. f., disponible en: https://www.notariosyregistradores. com/AULASOCIAL/2012-testamento-discapacidad-informe-medico-665-codigocivil.htm [consultado el 8 de abril de 2020].

Martínez, P., “Título vi. Capítulo it. Secciones 3. a 9. a”, [en línea], en Propuesta de código civil, Madrid, Tecnos, 2018, 549-561, disponible en: http://www.derechocivil.net/images/libros/obra_completa.pdf [consultado el 7 de abril de 2020].

Nieto, A. J., "El control social y la libre circulación de personas en tiempos del coronavirus", [en línea], La Ley, n. ${ }^{\circ}$ 9609, 7 de abril de 2020, 1-8, disponible en: https://diariolaley.laleynext.es/Content/Documento.aspx?params=H4sIAAAA AAAEAMtMSbF1CTEAAmMDc3MzE7Wy1KLizPw8WyMDI6CYkRIIIDOt 0iU_OaSyINU2LTGnOBUAH6d_yzUAAAA=WKE [consultado el 7 de abril de 2020].

Nogueira, A., "Confinar el coronavirus: entre el viejo derecho sectorial y el derecho de excepción", [en línea], El Cronista del Estado Social y Democrático de Derecho, n. ${ }^{\circ}$ 86-87, 2020, 22-31, disponible en: http://www.elcronista.es/ElCronista-n\%C3\%BAmero-86-87-Coronavirus.pdf [consultado el 30 de marzo de 2020].

Organización Mundial de la Salud, [en línea], 2020, disponible en: https://www. who.int/es [consultado el 15 de marzo de 2020].

Ramos, C., "Covid-19: la nueva enfermedad causada por un coronavirus", [en línea], Salud Pública de México, vol. 62, n. ${ }^{\circ}$ 2, 2020, 225-227, disponible en: http:// saludpublica.mx/index.php/spm/article/view/11276/11857 [consultado el 3 de abril de 2020]. 
Real Academia Española, s.v. “ágrafo/fa”, [en línea], 2020, disponible en: https:// dle.rae.es/?w=\%C3\%A1 grafo [consultado el 8 de abril de 2020].

Real AcAdemia EsPañola, s.v. “analfabeto/a”, [en línea], 2020, disponible en: https:// dle.rae.es/?w=analfabeto [consultado el 8 de abril de 2020].

Real AcAdemia Española, s.v. "procurar”, [en línea], 2020, disponible en: https:// dle.rae.es/?w=procurar [consultado el 8 de abril de 2020].

Ripoll, A., "Testamentos en caso de epidemia y en peligro de muerte", [en línea], Notarios y Registradores, 2020, 1-8, disponible en: https://www.notariosyregistradores.com/web/secciones/oficina-notarial/otros-temas/testamento-en-casode-epidemia-y-en-peligro-de-muerte/ [consultado el 7 de abril de 2020].

Vela, A. J., "El testamento en tiempo de epidemia: cuestiones esenciales", [en línea], La Ley, n. ${ }^{\circ}$ 9623, 2020, 1-8, disponible en: https://diariolaley.laleynext. es/dll/2020/04/29/el-testamento-en-tiempo-de-epidemia-cuestiones-esenciales [consultado el 6 de junio de 2020].

Velasco, F., "Estado de alarma y distribución territorial del poder", [en línea], El Cronista del Estado Social y Democrático de Derecho, n. ${ }^{\circ} 86-87,2020,78-$ 87, disponible en: http://www.elcronista.es/El-Cronista-n\%C3\%BAmero86-87-Coronavirus.pdf [consultado el 5 de abril de 2020].

\section{Fuentes legislativas}

España, Ley Orgánica del Notariado de 28 de mayo de 1862, [en línea], Gaceta de Madrid, 149, de 29 de mayo de 1862, disponible en: https://www.boe.es/datos/ pdfs/BOE//1862/149/A00001-00001.pdf [consultado el 7 de junio de 2020].

España, Código civil, [en línea], Gaceta de Madrid, 318, de 11 de noviembre de 1888, disponible en: https://www.boe.es/datos/pdfs/BOE//1888/316/A0044500445.pdf [consultado el 7 de junio de 2020].

España, Real Decreto de 24 de julio de 1889 por el que se publica el código civil, [en línea], Gaceta de Madrid, 206, de 25 de julio de 1889, disponible en: https:// www.boe.es/buscar/act.php?id=BOE-A-1889-4763 [consultado el 6 de junio de 2020].

España, Decreto de 2 de junio de 1944 por el que se aprueba con carácter definitivo el Reglamento de la organización y régimen del Notariado, [en línea], BOE, 
189, de 07/07/1944, disponible en: https://www.boe.es/buscar/doc.php?id=BOEA-1944-6578 [consultado el 7 de junio de 2020].

España, Ley de 24 de abril de 1958 por la que se modifican determinados artículos del código civil, [en línea], BOE, 99, de 25 de abril de 1958, disponible en: https:// www.boe.es/buscar/doc.php?id=BOE-A-1958-6677 [consultado el 7 de junio de 2020].

España, Ley 1/1973, de 1 de marzo, por la que se aprueba la Compilación del Derecho civil foral de Navarra, [en línea], BOE, 57, de 7 de marzo de 1973, disponible en: https://www.boe.es/buscar/doc.php?id=BOE-A-1973-330 [consultado el 7 de junio de 2020].

España, Constitución española, [en línea], BOE, 311, de 29 de diciembre de 1978, disponible en: https://www.boe.es/buscar/doc.php?id=BOE-A-1978-31229 [consultado el 6 de junio de 2020].

España, Ley Orgánica 4/1981, de 1 de junio, de los estados de alarma, excepción y sitio, [en línea], BOE, 134, de 5 de junio de 1981, disponible en: https://www.boe. es/buscar/doc.php?id=BOE-A-1981-12774 [consultado el 5 de junio de 2020].

España, Decreto Legislativo 79/1990, de 6 de septiembre, por el que se aprueba el Texto Refundido de la Compilación de Derecho civil de las Islas Baleares, [en línea], вогв, 120, de 2 de octubre de 1990, disponible en: https:/www.boe.es/ buscar/doc.php?id=BOIB-i-1990-90001 [consultado el 7 de junio de 2020].

España, Ley 2/2006, de 14 de junio, de Derecho civil de Galicia, [en línea], BOE, 191, de 11 de agosto de 2006, disponible en: https://www.boe.es/buscar/doc. php?id=BOE-A-2006-14563 [consultado el 7 de junio de 2020].

España, Real Decreto 45/2007, de 19 de enero, por el que se modifica el Reglamento de la Organización y Régimen del Notariado, aprobado por Decreto de 2 de junio de 1944, [en línea], BOE, 25, de 29 de enero de 2007, disponible en: https:// www.boe.es/buscar/doc.php?id=BOE-A-2007-1810 [consultado el 7 de junio de 2020].

España, Ley 10/2008, de 10 de julio, del libro cuarto del código civil de Cataluña, relativo a las sucesiones, [en línea], BOE, 190, de 7 de agosto de 2008, disponible en: https://www.boe.es/buscar/doc.php?id=BOE-A-2008-13533 [consultado el 7 de junio de 2020]. 
España, Anteproyecto de Ley, de la Generalitat, valenciana de sucesiones de 24 de julio de 2009, [en línea], disponible en: https://www.notariosyregistradores. com/PROYECTOS/proyectos\%20concretos/Valencia-sucesiones.pdf [consultado el 7 de abril de 2020].

España, Decreto Legislativo 1/2011, de 22 de marzo, del Gobierno de Aragón, por el que se aprueba, con el título de "Código del Derecho Foral de Aragón”, el Texto Refundido de las leyes civiles aragonesas, [en línea], вOA, 67, de 29 de marzo de 2011, disponible en: https://www.boe.es/buscar/doc.php?id=BOA-d-2011-90007 [consultado el 7 de junio de 2020].

España, Ley 5/2015, de 25 de junio, de Derecho Civil Vasco, [en línea], BOE, 176, de 24 de julio de 2015, disponible en: https://www.boe.es/buscar/doc.php?id=BOEA-2015-8273 [consultado el 7 de junio de 2020].

España, Ley 15/2015, de 2 de julio, de la jurisdicción voluntaria, [en línea], $B O E$, 158, de 3 de julio de 2015, disponible en: https://www.boe.es/buscar/doc. php?id=BOE-A-2015-7391 [consultado el 7 de junio de 2020].

España, Ley 10/2017, de 27 de junio, de las voluntades digitales y de modificación de los libros segundo y cuarto del código civil de Cataluña, [en línea], BOE, 173, de 21 de julio de 2017, disponible en: https://www.boe.es/buscar/doc. php?id=BOE-A-2017-8525 [consultado el 7 de junio de 2020].

España, Ley 4/2017, de 28 de junio, de modificación de la Ley 15/2015, de 2 de julio, de la jurisdicción voluntaria, [en línea], BOE, 154, de 29 de junio de 2017 , disponible en: https://www.boe.es/buscar/doc.php?id=BOE-A-2017-7483 [consultado el 7 de junio de 2020].

España, Ley Orgánica 3/2018, de 5 de diciembre, de protección de datos personales y garantía de los derechos digitales, [en línea], BOE, 294, de 6 de diciembre de 2018, disponible en: https://www.boe.es/buscar/doc.php?id=BOE-A-2018-16673 [consultado el 7 de junio de 2020].

España, Ley Foral 21/2019, de 4 de abril, de modificación y actualización de la Compilación del Derecho civil foral de Navarra o Fuero Nuevo, [en línea], BOE, 137, de 8 de junio de 2019, disponible en: https://www.boe.es/buscar/doc. php?id=BOE-A-2019-8512 [consultado el 7 de junio de 2020].

España, Real Decreto-Ley 6/2020, de 10 de marzo, por el que se adoptan determinadas medidas urgentes en el ámbito económico y para la protección de la salud 
pública, [en línea], BOE, 62, de 11 de marzo de 2020, disponible en: https://www. boe.es/buscar/doc.php?id=BOE-A-2020-3434 [consultado el 6 de junio de 2020].

España, Real Decreto 463/2020, de 14 de marzo, por el que se declara el estado de alarma para la gestión de la situación de crisis sanitaria ocasionada por el Covid-19, [en línea], вOE, 67, de 14 de marzo de 2020, disponible en: https://www. boe.es/buscar/doc.php?id=BOE-A-2020-3692 [consultado el 6 de junio de 2020].

España, Real Decreto 465/2020, de 17 de marzo, por el que se modifica el Real Decreto 463/2020, de 14 de marzo, por el que se declara el estado de alarma para la gestión de la situación de crisis sanitaria ocasionada por el Covid-19, [en línea], BOE, 73, de 18 de marzo de 2020, disponible en: https://www.boe.es/buscar/doc. php?id=BOE-A-2020-3828 [consultado el 6 de junio de 2020].

España, Resolución de 25 de marzo de 2020, del Congreso de los Diputados, por la que se ordena la publicación del Acuerdo de Convalidación del Real DecretoLey 6/2020, de 10 de marzo, por el que se adoptan determinadas medidas urgentes en el ámbito económico y para la protección de la salud pública, [en línea], BOE, 88, de 30 de marzo de 2020, disponible en: https://www.boe.es/buscar/doc. php?id=BOE-A-2020-4170 [consultado el 6 de junio de 2020].

España, Real Decreto 476/2020, de 27 de marzo, por el que se prorroga el estado de alarma declarado por el Real Decreto 463/2020, de 14 de marzo, por el que se declara el estado de alarma para la gestión de la situación de crisis sanitaria ocasionada por el Covid-19, [en línea], BOE, 86, de 28 de marzo de 2020, disponible en: https://www.boe.es/buscar/doc.php?id=BOE-A-2020-4155 [consultado el 6 de junio de 2020].

España, Real Decreto-Ley 10/2020, de 29 de marzo, por el que se regula un permiso retribuido recuperable para las personas trabajadores por cuenta ajena que no presten servicios esenciales, con el fin de reducir la movilidad de la población en el contexto de la lucha contra el Covid-19, [en línea], вOE, 87, de 29 de marzo de 2020, disponible en: https://www.boe.es/buscar/doc.php?id=BOE-A-2020-4166 [consultado el 6 de junio de 2020].

España, Real Decreto-Ley 11/2020, de 31 de marzo, por el que se adoptan medidas urgentes complementarias en el ámbito social y económico para hacer frente al Covid-19, [en línea], BOE, 91, de 1 abril de 2020, disponible en: https://www. boe.es/buscar/doc.php?id=BOE-A-2020-4208 [consultado el 6 de junio de 2020].

Italia, Regio Decreto de 16 de marzo de 1942, n. ${ }^{\circ} 262$, Approvazione del testo del codice civile (042U0262), [en línea], GU, 79, de 04/04/1942, disponible en: https:// 
www.normattiva.it/uri-res/N2Ls?urn:nir:stato:codice.civile:1942-03-16;262 [consultado el 7 de junio de 2020].

Portugal, Decreto-Ley 47344, de 25 de noviembre de 1966, código civil portugués 19, [en línea], disponible en: https://www.igac.gov.pt/documents/20178/358682/ C\%C3\%B3digo+Civil.pdf/2e6b36d8-876b-433c-88c1-5b066aa93991 [consultado el 7 de junio de 2020].

\section{Jurisprudencia citada}

\section{Auto de la Audiencia Provincial}

Auto Audiencia Provincial de Madrid, Sección 21. a, de 28 de marzo de 2011 (AC 2011\478).

\section{Sentencias de la Audiencia Provincial}

SAP de Guipúzcoa, Sección 2. a de 2 de junio de 1998 (AC 1998\1600).

SAP de Lugo, Sección Única, de 25 de enero de 2000 (AC 2000\3005).

SAP Ourense de 2 de diciembre de 2002 (AC 2002\2241).

\section{Sentencias del Tribunal Constitucional}

STC 82/2016, de 28 de abril, [en línea], вOE, 131, de 31 de mayo de 2016, disponible en: http:/hj.tribunalconstitucional.es/es-ES/Resolucion/Show/24936 [consultado el 7 de junio de 2020].

STC 110/2016, de 9 de junio, [en línea], BOE, 70, de 9 de junio de 2016, disponible en: http://hj.tribunalconstitucional.es/es-ES/Resolucion/Show/25013 [consultado el 7 de junio de 2020].

STC 192/2016, de 16 de noviembre, [en línea], BOE, 311, de 26 de diciembre de 2016, disponible en: http://hj.tribunalconstitucional.es/es-ES/Resolucion/Show/25162 [consultado el 7 de junio de 2020].

\section{Sentencias del Tribunal Supremo}

STs de 4 de febrero de 1943 (RJ 1943\126).

STS de 10 de julio de 1944 (RJ 1944\911). 
STS de 4 de octubre de 1957 (RJ 1957 2845).

STS de 19 de diciembre de 1959 (RJ 1959\4890).

STs de 8 de febrero de 1963 (RJ 1963\785).

STS de 28 de octubre de 1965 (RJ 1965\4747).

STS de 27 de septiembre de 1968 (RJ 1968\5163).

STs de 2 de julio de 1977 (RJ 1977\3256).

STS de 21 de junio de 1986 (RJ 1986\3788).

STS de 25 de abril de 1991 (RJ 1991\3029).

STS de 9 de mayo de 1990 (RJ 1990\3695).

STS de 27 de junio de 2000 (RJ 2000\5910).

sTs de 10 de junio de 2005 (RJ 2005\4365). 